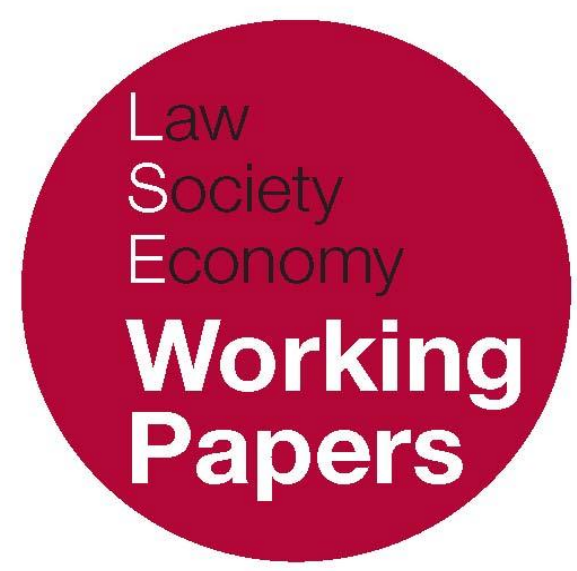

\title{
The Liquidity Dilemma and the Repo Market: \\ A Two-Step Policy Option \\ To Address the Regulatory Void
}

\author{
Paolo Saguato \\ LSE Law, Society and Economy Working Papers 21/2015 \\ London School of Economics and Political Science \\ Law Department
}

This paper can be downloaded without charge from LSE Law, Society and Economy Working Papers at: www.lse.ac.uk/collections/law/wps/wps.htm and the Social Sciences Research Network electronic library at: http://ssrn.com/abstract $=2692288$.

(C) Paolo Saguato. Users may download and/or print one copy to facilitate their private study or for non-commercial research. Users may not engage in further distribution of this material or use it for any profit-making activities or any other form of commercial gain. 


\title{
The Liquidity Dilemma and the Repo Market: A Two-Step Policy Option To Address the Regulatory Void
}

\author{
Paolo Saguato *
}

\begin{abstract}
A repurchase agreement (repo) is the sale of financial assets coupled with a promise to repurchase the same assets at a later date. With similar economic characteristics to secured loans and bank deposits, the repo market is one of the main sources of liquidity for financial markets and a vital segment of the US financial system. During the financial crisis of $2007-$ 2009 , when the markets crashed and the value of many assets dropped, repo lenders lost confidence in the repo market and massively withdrew their financing. Panic then ensued, drying up the liquidity in the markets. The over-reliance on short-term repo financing magnified the liquidity crunch, and financial institutions such as Lehman Brothers and Bear Stearns were brought to the brink of ruin. The crisis unveiled the deep opacity of the repo market, its proneness to runs, its structural weaknesses, the interconnectedness of its participants, the absence of stability buffers, and the lack of any comprehensive regulatory or supervisory framework. Astonishingly, however, the post-crisis regulatory agenda almost completely ignored the repo market. Though depicted as a reform intended to create a safer financial system, the Dodd-Frank Act essentially left untouched this important source of systemic risk.

After outlining the repo market and shedding new light on its structural instability, this paper presents an alternative narrative of the crisis by arguing that the structurally weak repo market triggered a liquidity crunch that halted the engine of the financial system. In doing so, the paper challenges the assumption that the crisis was caused merely by over-the-counter derivatives, securitization, and too-big-to-fail institutions.

This paper shows how the repo market has developed within the financial markets - free from the watchful eyes of regulators and capitalizing on regulatory arbitrage - and challenges the regulatory void of the Dodd-Frank Act vis-à-vis the repo market. Specifically, this paper presents an original two-step policy option for assessing the repo market, based on the lesson of the post-crisis reforms of over-the-counter derivatives market as well as the incremental role envisioned by lawmakers for "financial market infrastructure" and central clearing counterparties as stability mechanisms. This paper calls for the assessment of the necessity of a structural intervention in the repo market to fix the failures that currently characterize it, and suggests that more transparency, coupled with a strong financial market infrastructure, would make the repo market more transparent, stable, and resilient.
\end{abstract}

* LSE Fellow in Financial Regulation; LL.M. Yale Law School 2012; Ph.D. in Law University of Genoa 2013. I owe a special debt of gratitude to Professor Geoffrey P. Miller for his extraordinary insight, patience, and support in the preparation of this paper. Many thanks to Professors Jonathan Macey, Jerry Mashaw, Katharina Pistor, M. Todd Henderson, Guido Ferrarini, Jo Braithwaite, and Niamh Moloney for their comments and guidance with respect to earlier drafts. I also benefited greatly from discussions with Antoine Martin, Zoltan Pozsar, and David Murphy (in their personal capacity) and with Professors Viral V. Acharya and Richard Squire on issues pertaining to this paper. A special thanks to Barrie Kreinik for her excellent editing work. This project was partially supported by a Hauser Global Research Fellowship at the New York University School of Law. All errors are entirely my own. Grazie Eva! Grazie mamma, babbo e Fabio! I welcome comments at<paolo.saguato@gmail.com>. 


\section{INTRODUCTION}

Liquidity is the oxygen of financial markets and can be raised in different ways. ${ }^{1}$ The 2007-2009 financial crisis (the Crisis) revealed how heavily financial institutions relied on the securities funding market and on short-term financing contracts - namely repurchase agreements (repo) - to raise (short-term) liquidity over the last fifteen years. However, when this source of liquidity dried up and financial institutions ran out of liquidity, the markets panicked and the Crisis ensued. ${ }^{2}$ Countrywide Securities, Bear Stearns, Lehman Brothers, and Reserve Primary Fund are all examples of firms that collapsed dramatically when they ran out of liquidity. Indeed, these four financial institutions were caught in a liquidity crunch, and were all at the core of the Crisis and the subsequent larger economic crisis. $^{3}$

The market for repo - the sale of financial assets coupled with a promise to repurchase the same assets at a later date - was at the epicenter of the Crisis. Repos have similar economic characteristics to secured loans and bank deposits. They also have similar structural weaknesses: over-reliance on the stability of collateral value (as with secured loans) and proneness to "runs" (as with bank deposits). When the market crashed and the value of many assets dropped, repo lenders lost confidence in the repo market and massively withdrew their financing. Panic then ensued, drying up the liquidity in the market. Despite the repo market's significant role in the Crisis, however, there has been a general regulatory void visà-vis the repo market. ${ }^{4}$ Neither domestic nor international policymakers prioritized reforming the repo market in the post-Crisis reform agenda, and

\footnotetext{
1 See William C. Dudley, President and C.E.O., N.Y. Fed. Res., Risk of Wholesale Funding, Welcoming remarks at the Federal Reserve Bank of New York workshop on the "Risk of Wholesale Funding" New York City (Aug. 12, 2014) transcript available at http://bis.orf/review/r140818d.htm; stating 'liquidity is in turn crucial to the functioning of the financial system.'

Liquidity is a central concept for the study of financial market. Scholars identify three main dimensions of liquidity. (1) Market liquidity indicates 'the ability to trade a security quickly at a price close to its consensus value;' (2) funding liquidity refers to the access to sufficient cash reserves or the 'ability to obtain credit at acceptable terms;' (3) monetary liquidity describes "broader monetary aggregates;" see THIERRY FOUCAULT, Marco Pagano, Ailsa Röell, Market Liquidity - Theory, Evidence, and Policy (2014). Recently the International Monetary Fund (IMF) in its Global Financial Stability Report recommended 'measures to bolster both the level of market liquidity and its reliance.' See IMF, Market Liquidity - Resilient of Fleeting?, in Global FinANCIAL STABILITY REPORT (2015); for a comment on the IMF's contribution on market liquidity, Martin Wolf, Beware of the Liquidity Delusion, Fin. Times, Oct. 6, 2015, available at http://www.ft.com/cms/s/0/c8c2cc44-68fa-11e5-a57f-21b88f7d973f.html\#axzz3ntpExcUr.

2 See Gary b. Gorton, Slapped by the Invisible Hand: the Panic of 2007 (2001) [hereinafter Gorton, Slapped by the Invisible Hand].

3 See Timothy F. Geithner, Stress Test: Reflection on Financial Crisis (2014).

4 See David Skeel, The New Financial Deal - Understanding the Dodd-Frank Act and its (UNINTENDED) CONSEQUENCES 96-97 (2011), emphasizing 'lawmakers left an important source of rusk essentially untouched: investment banks' reliance on very short-term repo financing ' and 'Dodd Frank ignores the repo market almost completely'; Peter Eavis, Bernanke Quietly Criticizes Lack of Repo Reforms, N. Y. Times, Apr. 10, 2012, http://dealbook.nytimes.com/2012/04/10/bernanke-quietly-admonishes-lackof-repo-reforms/?nl=business\&emc=edit_dlbkam_20120411\&_r=0.
} 
commentators left the repo market at the edge of the debate on the Crisis. ${ }^{5}$ This paper explores why the current regulatory void exists, assesses the failures and vulnerabilities of the repo market, and engages in a policy discussion on how to strengthen this crucial element of the "plumbing" of the financial system. ${ }^{6}$

The Crisis showed the repo market to be both a central component of the financial system and a source of structural vulnerabilities and externalities. ${ }^{7}$ As an alternative source of financing and liquidity for the traditional banking sector, the repo market is commonly included within the "shadow banking" system. ${ }^{8}$ Yet, even though regulators, ${ }^{9}$ policy makers, and academics called for "tackling" the "shadow banking" system, ${ }^{10}$ the repo market - despite being a main element of

\footnotetext{
5 See Section V; see infra notes 8, 137-141 and accompanying text.

${ }^{6}$ The reference to the repo market as an element of the "plumbing" of the financial system was first used by Darral Duffie in one of its seminal work; see Duffie, Replumbing Our Financial System, infra note 10, at 910 .

7 See, e.g. Gorton, Slapped by the Invisible Hand, supra note 2; Viral V. Acharya et al., Regulating Wall Street - the Dodd-Frank Act and the New Architecture of global Finance (2011); Gary B. Gorton \& Andrew Metrick, Securitized Banking and the Run on Repo, 104 J. Fin. Econ. 2012, 425 (focusing on the combination of securitization and repo finance in the financial crisis).

8 See, e.g. For a Richard Carnell, Jonathan Macey \& Geoffrey P. Miller, The Law of Banking AND FinANCial Institutions 531-536 (5th ed. 2013); Zoltan Pozsar et al., Shadow Banking (Fed. Reserve Bank of New York Staff Reports No. 458 July 2010, revised Feb. 2012), available at http://www.newyorkfed.org/research/staff_reports/sr458.pdf; Stijn Claessens et at., Shadow Banking: Economics and Policy (IMF Staff Discussion Note 2012), available at http://www.imf.org/external/pubs/ft/sdn/2012/sdn1212.pdf: Steven L. Schwarcz, Regulating Shadows: Financial Regulation and Reasonability Failure, 70 WASH. \& LEE L. REV. 1781 (2013). Scholars have debated the definition of shadow banking, and have provided their perspectives on what should and should not be included in that concept. The results, however, are inconsistent, and despite the presence of a few commonly agreed-upon structural elements, the shapes and borders of the shadow banking sector are still not completely clear.

${ }^{9}$ See, e.g. Daniel K. Tarullo, Governor, Bd. of Governors of the Fed. Res., Shadow Banking and Systemic Risk Regulation, Remarks at the Americans for Financial Reform and Economic Policy Institute Conference, Washington, D.C. (Nov. 22, 2013) (transcript available at http://www.federalreserve.gov/newsevents/speech/tarullo20131122a.htm).

10 See, e.g. Gary B. Gorton \& Andrew Metrick, Regulating the Shadow Banking System (261 Brookings Papers on Economic Activity Fall 2010), available at

http://www.brookings.edu/ /media/projects/bpea/fall\%202010/2010b_bpea_gorton.pdf (analyzing the structure of the shadow banking system and offering a new regulatory framework for the system. As a first step, the authors propose, on the one hand, to narrow money market mutual funds' activities, and on the other, to create narrow funding banks (NFB) that are only involved in securitization and fund their activities only through repo activities. As a second step, they argue for the creation of two types of repo: one, only offered by NFBs and commercial banks, performing a monetary function, and the other, offered by ad hoc licensed entities, performing other forms of short-term financing); Darrell Duffie, Replumbing Our Financial System: Uneven Progress, 9 INT'L J. CENT. BANKING 252 [hereinafter Duffie, Replumbing Our Financial System] (analysing the role of clearing banks in the tri-party repo market and arguing for a regulation of the tri-party market infrastructure as regulated utilities); Morgan Ricks, $A$ Regulatory Design for Monetary Stability, 65 VAND. L. REV. 2013, 1290 (suggesting that the money-claim market should be rebuilt around a public-private partnership (PPP) system, in which issuers of moneyclaims have to be licensed and subject to portfolio restrictions and capital requirements, and in which the government provides a safety net to any licensed entity); Carolyn Sissiko, Shadow Banking: Why Modern Money Markets are Less Stable than 19th c. Money Markets but Shouldn't Be Stabilized by a 'Dealer of Last Resort', USC Law Legal Studies Paper No. 14-21, 2014, available at http://papers.ssrn.com/sol3/papers.cfm?abstract_id=2392098 (focusing on the different roles played by dealer banks and commercial banks ion the financial system).
} 
the money market and a widely used source of capital allocation - has thus far barely been explored by regulators and legal commentators. ${ }^{11}$

This paper wades into this void and targets a specific segment of "shadow banking": the repo market. Specifically, this paper provides an analysis of the repo market by focusing on its role in the Crisis and on the regulatory and institutional failures in monitoring and managing the underlying risk. The paper argues that repo reforms might be needed to correct some of the structural market failures that the Crisis revealed, namely the deep opacity of the market, its structural weaknesses, the interconnectedness of the few market actors, the absence of stability buffers, the proneness of the repo market to panic and runs, and the lack of any comprehensive regulatory or supervisory framework. It demonstrates that the repo market is an important source of short-term collateralized financing for financial institutions and market participants. Indeed, statistics from the New York Federal Reserve (NY Fed), and the International Capital Market Association (ICMA) quantify the current size of the American and European repo markets at more than $\$ 10$ trillion. $^{12}$

Repo has a distinctive economic and legal structure. A repo is a form of short-term collateralized borrowing - or alternatively, a form of short-term wholesale funding - structured as a sale and repurchase agreement. In a basic repo, a firm "borrows" cash through the sale of financial instruments (typically government bonds, corporate bonds, agency securities, and other forms of debt or equity instruments) to a "lender". The sale contract is coupled with a repurchase agreement, wherein the "borrower" agrees to buy back the securities previously transferred to the lender at a higher price and future date. ${ }^{13}$ The transferred securities serve as collateral in the deal. Generally, the collateral is subject to a "haircut", which expresses, via a percentage, the difference between the market value of the pledged collateral and the amount borrowed, and reflects the perceived riskiness of the assets.

From an economic perspective, repos serve an important role in credit intermediation, in liquidity provision, and more broadly in the money market. Repos are money instruments and secured providers of short-term liquidity. They intervene in the market by combining and matching the financial needs of opposite parties, either "cash pools" (i.e., mutual funds or corporate treasuries) or "securities pools" (i.e., banks, broker-dealers, and securities lenders). In the repo

\footnotetext{
11 See, e.g. Financial Stability Board, Strengthening Oversight and Regulation of Shadow Banking Policy Framework for Addressing Shadow Banking Risks in Securities Lending and Repos (Aug. 29, 2013), available at http:/ / www.financialstabilityboard.org/publications/r_130829b.pdf [hereinafter FSB, August 2013 Report]; NY Fed, White Paper on Tri-Party Repurchase Agreement (Repo) Reform (May 17, 2010) available at http://www.newyorkfed.org/banking/tpr_infr_reform.html; European Commission, Green paper on Shadow Banking (Mar. 19, 2012), available at http://ec.europa.eu/internal_market/finances/shadow-banking/index_en.htm\#maincontentSec3; see infra note 120 and accompanying text.

12 For a detailed analysis on the repo market size see Section II.A.2.

${ }^{13}$ For more details see Section III.
} 
market, securities dealers find the source of liquidity that they need in order to finance their inventory and short-term or long-term investments; to run their treasury activities; and, more generally, to access short-term liquidity - here is the parallelism of repos with secured loans. On the other side, mutual funds and institutions with a high cash supply look for profitable yields and secured opportunities in which they can deposit their extra liquidity as it earns interest here is the parallelism of repos with bank deposits. ${ }^{14}$ Thus, a repo is a mechanism that aligns the financial needs of both of the above-mentioned parties and transforms them into valuable marketable transactions.

One peculiarity of the repo market, which it shares with the traditional commercial depository banking system, is the role of repo in asset maturity transformation, which exposes it to the risk of runs. Repos perform maturity transformation by creating short-term claims ("short-term loans") that can be "monetized" or invested in long-term financial assets. In other words, repo dealers borrow in the short term, but can invest in long-term project. The maturity mismatch between long-term assets and short-term liabilities of repo borrowers makes them vulnerable to the risk of run and exposes the repo market to procyclical behaviours. This risk is further exacerbated by the maturity of the contract. Repos are in fact generally short-term - often overnight - transactions that are frequently concluded in the late afternoon of the first day, mature by the middle of the second day, and are rolled over (refinanced) on the third day. This makes repos structurally similar to demand deposits, in which the depositor, namely the repo lender, can at any time withdraw its funds by deciding not to roll over its repo financing.

As experienced in the midst of the Crisis, a run on the repo market is triggered by large withdrawals by repo lenders. Such withdrawals, which are similar to traditional banking deposit withdrawals, can be triggered when the repo lender asks for a higher haircut or decides not to roll over its financing contract. In the first scenario, the borrower is asked to post additional collateral to cover any (perceived) increased risk in the transaction or an unexpected decline in the value of the collateral originally posted. If the borrower fails to do that, the contract is terminated. Conversely, in the event the lender chooses not to roll over, the borrower has two options: it may buy back the securities (i.e., pay back its loan) or, if it lacks the liquidity to conclude the repurchase leg of the deal, it can walk away from the contract, leaving the collateral with the lender.

In a normal market scenario, the lender can cover its exposure by selling the collateral on the market. However, as the Lehman Brothers and Bear Stearns examples - in which both investment banks heavily relied on very short-term repo

14 See Jonathan R. Macey \& Geoffrey P. Miller, Nondeposit Deposits and the Future of Bank Regulation, 91 MiCH. L. REv. 237 (1992) (discussing capital market instruments that depository institutions can use to obtain funds and that are not treated as deposits subject to reserve requirements or deposit insurance assessment). 
financing to support their activities -15 show, the decision of a repo lender not to roll over its repo financing or to ask for an increased haircut can have multiple serious, market-wide fallouts. First, it can directly affect the reputation of the repo borrower, which might result in a decreased likelihood that other parties will extend credit and enter into new deals with that counterparty. Second, it can reduce the perception of reliability of the pledge collateral, which can result in a market-wide depreciation of a specific class of collateral and then in fire sales of collateral as holders of a specific class of securities try to liquidate their securities on the market at a discounted price. ${ }^{16}$ Third, it can undermine the confidence in the repo market as a whole. Therefore, just as a commercial bank panic can result in massive depositors' withdrawals, consequential risk of bank failure, and a potential panic spread throughout the whole banking and economic system, a loss of confidence in the repo market can result in a run on the short-term financing market, which can consequently impact the liquidity of the entire financial market.

The Crisis provided us with a clear example of how a crisis in the repo market affects both repo borrowers and lenders. With regard to repo borrowers, Lehman Brothers and Bear Stearns are the paradigmatic cases. For repo lenders, a classic example was Reserve Primary Fund, a money market mutual fund (MMMF) that was caught in a downturn spiral as the value of the collateral received in its repo transactions depreciated. When Reserve Primary Fund consequently tried to liquidate its repo positions, it "broke the buck" and its share price fell below $\$ 1,{ }^{17}$ requiring a systemic intervention by the Fed to stabilize the whole MMMF industry. ${ }^{18}$

15 A peculiar use of repo contracts is the so-called "repo 105" mechanism, created by Lehman Brothers to push risky assets out of its balance sheets by exploiting accounting rules. For a reconstruction of the “repo 105" mechanism see Michael J. De La Merced \& Julia Werdigier, The Origins of Lehman's Repo 105, March 12, 2010, available at http://dealbook.nytimes.com/2010/03/12/the-british-origins-of-lehmansaccounting-gimmick/?_r=0; Tracy Alloway, Repo 105, FTAlphaville March 12, 2010, available at http://ftalphaville.ft.com//2010/03/12/173241/repo-105/.

16 See, for instance, the case of asset back securities in the run-up to the Crisis; The Financial Crisis Inquiry Committee: Final Report of the National Commission on the Causes of the Financial and Economic Crisis in the United States (2011), 113-115 [hereinafter Financial Crisis Inquiry Report], available at http://www.gpo.gov/fdsys/pkg/GPO-FCIC/pdf/GPO-FCIC.pdf.

17 See Christopher Condon, Reserve Primary Money Fund Falls Below \$1 a Share, Bloomberg (April 24, 2010), Sept. 16, 2008, http://www.bloomberg.com/apps/news?pid=20601087\&sid=aAjlpHOSthQA.

${ }_{18}$ On the structure and regulation of MMMF, see John Morley, The Separation of Funds and Managers: $A$ Theory of Investment Fund Structure and Regulation, 123 YALE L.J. 1228 (2014). On the role of MMMF in the Crisis and on regulatory responses see Jonathan Macey, Reducing Systemic Risk: The Role of Money Market Mutual Funds as Substitutes for Federally Insured Deposits, 17 STAN J.L. Bus. \& FIN. 131, (2011-2012) at 133138, 143-151; Jeffrey N. Gordon, Perspectives on Money Market Mutual Fund Reform, Submission to the Committee on Banking, Housing and Urban Affairs, U.S. Senate (June 21, 2012),

http://www.law.columbia.edu/null/download?\&exclusive=filemgr.download\&file_id=6217 22. In the aftermath of the Crisis, the SEC has extensively regulated MMMF. See SEC, Money Market Fund Reform, Amendments to Form PF: Final Rule, Release No. 33-9616, FR-84; File No. S7-03-13 (July 23, 2014) (codified as amended in scattered sections of 15 U.S.C. and 17 C.F.R); Luis A. Aguilar, Commissioner, SEC, The Importance of Being Earnest About Liquidity Risk Management (Sept. 20, 2015) available at https://www.sec.gov/news/statement/aguilar-liquidity-risk-management.html. 
Internationally, the Crisis wreaked havoc in global financial markets, triggering extensive regulatory debates on how to restore confidence and stability in the financial system. The collapse of Lehman; the near collapse of Bear Stearns, Countrywide Securities, and Reserve Primary Fund; and the subsequent domino effect of such events on the world's markets were all symptoms of the financial system's overarching weaknesses, and showed the vulnerabilities of the repo market in particular. ${ }^{19}$ The market turmoil revealed the repo market's fragility and raised questions as to whether and how repos and the short-term wholesale funding market should be restructured or regulated, as well as what measures should be implemented to strengthen repo market reliability and stability.

The US repo market, which originally developed as an over-the-counter (OTC) bilateral market, has expanded over time and diverged into two markets: a bilateral and a tri-party. In the former, two parties mutually agree to conclude a repo contract and arrange the transfer and management of the collateral. In the latter, by contrast, the parties set up a multi-party deal that is assisted and directed by a third entity. That entity, which is not a formal party to the contract, acts as an intermediary and performs all of the administrative activities connected to the deal, i.e., handling the loan, managing the collateral, providing (when necessary) intra-day liquidity, assisting the rollover of the contract, etc. ${ }^{20}$

Significantly, the recent financial turmoil revealed structural fragilities in the repo market's foundations: the features of the repo market that denote market failures and potential risks are connected to the current structure of the repo business. Such weaknesses exacerbate the risk of contagion in the financial system. If not promptly addressed, these weaknesses could reach systemic proportions and result in a new crisis for the financial system - with regulators and market participants being responsible, yet again, for another regulatory failure. This is apparent for a variety of reasons.

First, both the bilateral and tri-party repo markets are extremely opaque. Although more data have recently been gathered on the tri-party repo market, the actual size of the web of repo transactions remains murky, especially for bilateral repo. From a public policy perspective, this situation limits the capacity of regulators to oversee the market, to assess its underlying risk, and to effectively intervene in the event of a crisis. From a market perspective, the lack of information on market participants, collateral type and exposure, and repo pricing reduces market efficiency by increasing the cost of risk-pricing and evaluating the market trends in collateral.

\footnotetext{
${ }^{19}$ The study of the regulatory failures that contributed to the exacerbation of the financial crisis goes beyond the scope of this paper; for a comprehensive overview of "what happened" during the crisis see, among others, Gary Gorton \& Andrew Metrick, Getting Up to Speed on the Financial Crisis: A One-WeekendReader's Guide, 50 J. ECON. LITER. 128 (2012).

${ }^{20}$ It is worthwhile to note that the repo market developed differently in the US than in the EU, where the market is relatively more structured around a financial market infrastructure. More than a third of

European repos are in fact traded on electronic trading platforms; roughly $10 \%$ of repos are concluded in the tri-party market; and the majority of repo transactions are cleared through central clearing counterparties.
} 
Second, the repo market is characterized by a high level of concentration: market participants are a limited group of highly interconnected players, and collateral clearing activities in the tri-party repo market are dominated by the oligopolistic position of two main clearing banks. ${ }^{21}$ The market is grounded upon its participants' reputation. However, as seen during the Crisis, the absence of reputational buffers and safeguard mechanisms makes the market extremely unstable and unpredictable. The highly concentrated market, restricted access to new participants, and high reputational costs - both in terms of entry costs into the market and "punitive" exit costs - limit the efficiency and potential expansion of the repo market itself.

Third, the clearing banks in the tri-party market comingle two activities that might result in a dangerous conflict of interest. At one level, these clearing banks act as big financial institutions involved in financial markets; on another level, they serve a "financial infrastructure" function by acting as market utilities, providing a "public good" to market participants. Thus, because repo clearing is performed by these banks, which are active participants in the financial markets, regulators are compelled to intervene in a crisis to save these "too big to fail" - or more precisely, "too important to fail" - banks from failure. Because these institutions know that they are too important to fail, a problem of moral hazard emerges: a clearing bank may decide to get involved in risky investments on the assumption that its role as a financial infrastructure in the repo market will guarantee a public rescue in any situation.

Fourth, as described above, the repo market is prone to procyclicality and the risk of run, and lacks private contractual mechanisms to internalize the risk of panic and contagion among its participants. The lender's ability to re-hypothecate the received collateral - i.e., to use the collateral to finance another transition together with the exemption from "automatic stay" under the bankruptcy regime further exacerbate the potential instability of the repo market.

Despite being an essential element of the plumbing of the financial system, the repo market is far from being immune to runs and crises. Furthermore, it has many elements in common with the pre-Crisis conditions of the OTC derivatives market and a few well-known weaknesses of the traditional banking system. Any new repo market reform agenda - whether it be sponsored by privately driven initiatives or by a public regulatory intervention - should, therefore, aim to increase transparency, strengthen confidence and stability in the market, contain systemic risks, reduce procyclicality and the risk of run, and foster competition. Lawmakers should look at the post-Crisis regulatory initiatives undertaken by private industry and public regulators to restore the stability of the derivatives

${ }^{21}$ The two operating clearing banks in the tri-party repo market are J.P. Morgan Chase and Bank of New York Mellon. 
market as a potential model with which to inform structural modifications to the repo market. ${ }^{22}$

In the pre-Crisis scenario, institutional and structural failures resulted in the absence of any comprehensive or systematic oversight of the repo market and its participants. The repo market resides in the penumbral area at the intersection of banking and securities regulation. Many repo market participants were subject to the supervision and regulation of the Securities and Exchange Commission (SEC), while others were under the oversight of the Fed. Regulators were aware of the heavy reliance of financial institutions on short-term financing, but no actions were taken to make such financing safer. ${ }^{23}$ Similarly, in the post-Crisis agenda, the repo market was treated as a minor issue; most of the airtime was devoted to more "news-sexy" and "exotic" issues such as derivatives, bankers' remuneration, and the potential breakup of big financial institutions - the "bad guys" on Wall Street. The Dodd-Frank Act, a massive piece of legislation that was intended to rebuild confidence and stability in the financial system, ${ }^{24}$ left the repo market untouched, but with regulators and market participants well aware of its persisting vulnerabilities..$^{25}$

${ }^{22}$ For an analysis of the pre-Crisis regulatory scenario of OTC derivatives, see Paolo Saguato Private Regulation in the Credit Default Swaps Market: The Role of ISD A in the New Regulatory Scenario of CDSs, in THE Governance AND Regulation of InTERnATIONAL FinANCE 32 (Geoffrey P. Miller \& Fabrizio Cafaggi eds., 2013), Lynn Stout, Derivatives and the Legal Origin of the 2008 Credit Crisis 1. Bus. L. REV. 1 (2011); Dan Awrey, Complexity, Innovation and the Regulation of Modern Financial Markets, 2 HARV. Bus. L. REV. 235 (2012).

23 An attempt to regulate the over-reliance on short-term funding can be found in the "liquidity coverage ratio" and the "net stable funding ratio" stated in the Basel III Accord, but yet not implemented in any states; see BASEL COMM. ON BANKING SUPERVISION, BASEL III: LIQUIDITY COVERAGE RATIO AND LIQUIDITY RISK (Jan. 2013), at 8-10.

24 Dodd-Frank Wall Street Reform and Consumer Protection Act of 2010, Pub. L. 111-203, Jul. 21, 2010, 124 Stat. 1376 (\$ 324). In the 848 pages of this piece of legislation, the phrase "repurchase agreement" appears only 37 times, 25 of which are found in the "Definitions" section. The only section that tangentially addresses the repo market is Sec. 610, which limits the amount of short-term debt a systemically important firm is permitted to have: 'Lending limits applicable to credit exposure on derivative transactions, repurchase agreements, reverse repurchase agreements, and securities lending and borrowing transactions.'

25 See Ben. S. Bernanke, Chairman, Bd. of Governors of the Fed. Res., Reflections on a Year of Crisis, remarks at the Federal Reserve Bank of Kansas City's Annual Economic Symposium, Jackson Hole, Wyoming (Aug. 21, 2009) (transcript available at

http://www.federalreserve.gov/newsevents/speech/bernanke20090821a.htm); id., Fostering Financial Stability, Remarks at the 2012 Federal Reserve Bank of Atlanta Financial Markets Conference, Stone Mountain, Georgia (Apr. 9, 2012) (transcript available at http://www.federalreserve.gov/newsevents/speech/bernanke20120409a.htm); id., Some Reflections on the Crisis and the Policy Response, Remarks at the Russell Sage Foundation and The Century Foundation Conference on "Rethinking Finance," New York, New York (Apr. 13, 2012) (transcript available at http://www.federalreserve.gov/newsevents/speech/bernanke20120413a.htm); id., Monitoring the Financial System, Remarks at the 49th Annual Conference on Bank Structure and Competition sponsored by the Federal Reserve Bank of Chicago, Chicago, Illinois (May 10, 2013) (transcript available at http://www.federalreserve.gov/newsevents/speech/bernanke20130510a.htm); id., The Crisis as a Classic Financial Panic, Remarks at the Fourteenth Jacques Polak Annual Research Conference, Washington, D.C. (Nov. 8, 2013) (transcript available at http://www.federalreserve.gov/newsevents/speech/bernanke20131108a.htm); Daniel K. Tarullo, Governor, Bd. of Governors of the Fed. Res., Shadow Banking After the Financial Crisis, Remarks at the Federal Reserve Bank of San Francisco Conference on Challenges in Global Finance: The Role of Asia, San Francisco, California (June 12, 2012) (transcript available at 
This paper contributes to the shadow banking system regulatory debate and focuses specifically on the repo market by proposing a two-step policy option to make the repo market more transparent, stable, and resilient. The first step is built on the Financial Stability Board (FSB) and European Commission (EC) initiatives and aims at increasing transparency in the market by requiring mandatory reporting of repo transactions. This solution would impose on market participants circumscribed macroprudential measures in terms of higher transparency, and would contribute to increased disclosure at the transaction level. While this would improve risk pricing through market participants, it would not address the delicate issues related to the structural and systemic fragilities of the repo market. ${ }^{26}$

Once transparency is achieved, the second step calls for the involvement of the financial market infrastructure in the repo market. The financial market infrastructure step is modelled on some of the international principles found in the post-Crisis reforms of OTC derivatives and envisions a central role for trading venues and central clearing counterparties (CCPs) in the repo market. This step pushes for the clearing of standardized repos via standalone clearing utilities rather than clearing banks, as occurs today. Clearing repos via standalone clearing utilities, which perform their financial "infrastructural" activities with specific risk and capital requirements and effective risk management, would strengthen the market, increase efficiency, and consequently reduce systemic risk and contain liquidity risk. ${ }^{27}$ In addition, keeping these clearing entities under the supervision of public authorities (with the possibility of accessing public financial support in case of distress) would contain the risk of run and provide more stability to the whole financial system. ${ }^{28}$

Standardized and centrally cleared repos should be traded in trading venues. This would increase the transparency of the market, reduce the entry and reputational costs for new market players, and reduce transactional and operational costs for current members because the trading venues - exchanges or electronic platforms - would make more pre- and post-trading information available to the public and to participants.

This paper argues that reforms are necessary in order to build a safer and more stable repo market and encourages policymakers and the financial industry to learn from the progress in post-Crisis OTC derivatives regulation, in which the dialogue between the private and public sectors resulted in a safer and more transparent derivatives market. For example, in the OTC space, trade repositories

http://www.federalreserve.gov/newsevents/speech/tarullo20120612a.htm); Timothy F. Geithner, Written Testimony before the House Financial Services Committee (Apr. 20, 2010) (transcript available at http://www.treasury.gov/press-center/press-releases/Pages/tg645.aspx).

26 See Section V.A.

27 See Jerome H. Powell, Governor, Bd. of Governors of the Fed. Res., Clearing in an Interdependent World, Remarks at The Clearing House Annual Conference, New York, N.Y. (Nov. 17, 2013) (transcript available at http://www.federalreserve.gov/newsevents/speech/powell20151117a.htm) exploring the benefits of expanding central clearing for repo transactions.

28 See Section V.B. 
and reporting mechanisms for derivatives have been finalized; CCPs - after complying with new risk management and capital requirements - have begun to offer clearing services for a broader range of derivatives and are exploring new opportunities in the management of collateral. ${ }^{29}$ This is the time to learn from these regulatory advancements in the derivatives market, which can all be extended and adapted to the repo market by industry-driven initiatives and/or without excessive regulatory costs.

The roadmap for this paper is as follows.

An introduction to the repo market is put forth in Part I. Part II presents an overview of the repo market that highlights the market size, dynamics, and relationship to the larger financial system. This section will also present four case studies - Countrywide Securities, Lehman Brothers, Bear Stearns, and Reserve Primary Fund - and will investigate how the repo market acted in the Crisis, what role it played, and how regulators and agencies acted vis-à-vis the market.

Part III centres around the contractual aspects of a repo. Specifically, the paper will examine standard "boilerplate" repo agreements, namely the 2011 Global Master Repurchase Agreement (GMPA) drafted by ICMA for the UK market (now the principal master agreement for all cross-border and many domestic repo transactions) ${ }^{30}$ and the 1996 Master Repurchase Agreement (MRA) drafted by the Securities Industry and Financial Markets Association (SIFMA) for the US repo market. The paper then analyses the legal structure and treatment of repo and compares it to secured loans and securities lending. Subsequently, the paper addresses the economic functions of the repo market and its transactions, focusing on its central role as a short-term liquidity provider that lubricates the financial mechanisms of other markets.

Part IV identifies and analyses the structural weaknesses in the regulation and oversight of the repo market and the market failures that brought those weaknesses to light. It also considers the reasons for the regulatory inaction vis-àvis the repo market in the post-Crisis regulatory debate.

The paper's core, Part V, acknowledges the current scholarly debate and assesses whether there is a case for reforming or regulating the repo market. Specifically, Part V offers an original policy option drawn from the regulatory experience of the OTC derivatives market. This two-step option - which would promote a more sound, resilient, transparent, and effective repo market - is laid out along a spectrum that is built on the central roles of transparency and financial market infrastructure. Finally, Part VI provides some brief conclusions.

\footnotetext{
29 See FSB, Eighth Progress Report on Implementation of OTC Derivatives Market Reforms (Nov. 7, 2014), available at http://www.financialstabilityboard.org/2014/11/eighth-progress-report-on-implementation-of-otcderivatives-market-reforms/.

30 See ICMA, Frequently Asked Questions on Repo 17-18 (May 2015), available at http://www.icmagroup.org/Regulatory-Policy-and-Market-Practice/short-term-markets/RepoMarkets/frequently-asked-questions-on-repo/ [hereinafter FAQ].
} 


\section{DIVING INTO THE “REPO” WORLD}

Before jumping into structural and policy analyses of the repo market, we should take a look at how a repo is structured. ${ }^{31}$ Imagine the following transaction between a securities dealer and a cash investor, in this case a MMMF: the securities dealer is in need of cash to finance its inventory and the MMMF is looking for a safe, short-term investment in which to deposit its cash reserves. Here is where the repo steps in. The two parties reach a deal: the securities dealer borrows $\$ 100$ from the MMMF for a week by selling $\$ 100$ worth of US Treasuries to the MMMF, with the sold US Treasuries acting as collateral for the transaction. At the same time, the securities dealer agrees to repurchase the US Treasuries from the MMMF for $\$ 105$ after one week, with the $\$ 5$ difference representing the interest on the principal amount of the loan - more specifically the repo rate. 32

Securities dealer sells $\$ 102$ worth of securities for $\$ 100$ in cash

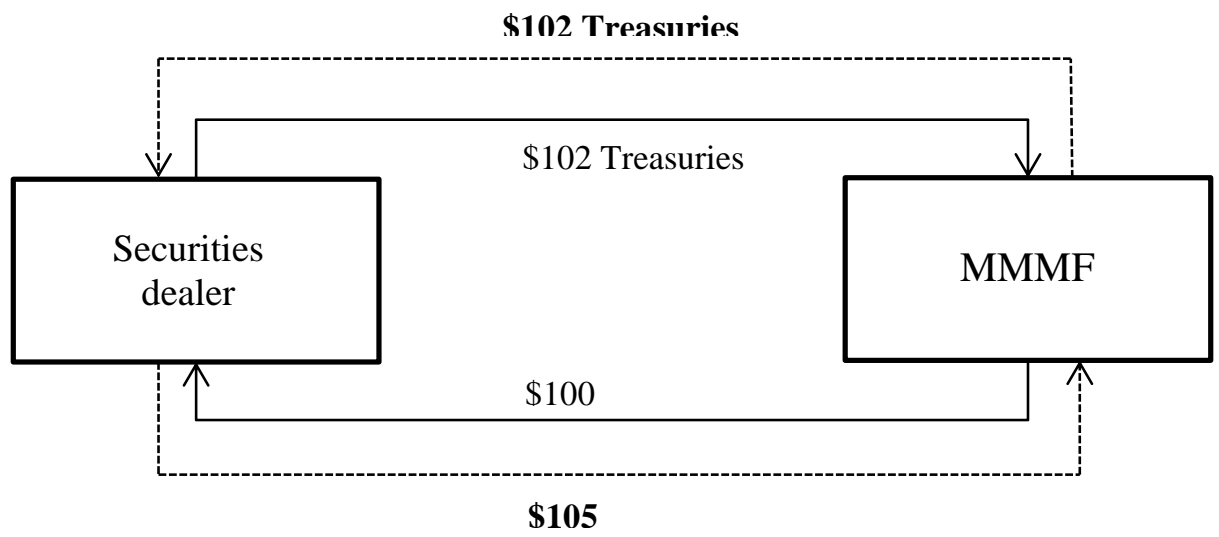

At maturity, the securities dealer pays $\$ 105(\$ 100+\$ 5$ "interest") in cash to repurchase the securities

At the end of the week, the MMMF faces three scenarios:

1. The securities dealer repurchases the transferred US Treasuries and pays the agreed $\$ 105$.

2. The securities dealer and the MMMF agree to "roll over" the repo; in other words, they agree to refinance the positions.

3. The securities dealer defaults on the transaction and does not repurchase the transferred securities.

${ }^{31}$ For a detail analysis of the evolution of the US repo market, see Viral V. Acharya \& Sabri Öncü, The Repurchase Agreement (Repo) Market, in Regulating Wall Street: The Dodd-Fran Act and the New ARCHitecture of Global FinANCE, 319, 323-343 (Viral V. Acharya et al. eds., 2011).

32 Id. at $312-322$. 
If at the end of the week the securities dealer is not able to pay back the $\$ 105$ loan by re-purchasing the bonds, the MMMF keeps the property of the collateral. However, the MMMF could default on its obligation to return the securities at the maturity of the contract, in which case the securities dealer becomes entitled to keep the $\$ 100$. Both parties, in fact, acquire the legal right to the transferred assets - cash and securities - which they can pledge as collateral in other transactions or use for any given purpose.

Although counterparty credit risk is mitigated by the economic structure of the transaction and the transfer of collateral, that risk still persists in the collateral. The value of the transferred securities can in fact deviate from the principal value of the loan over the lifespan of the contract. To protect against the fluctuation risk of the collateral value, parties generally apply a haircut or an initial margin. Simply put, if the MMMF is concerned about the risk of devaluation of the securities, it will lend $\$ 100$ to the dealer, but it will require the dealer to transfer US Treasuries worth $\$ 102$, thereby imposing a $2 \%$ haircut on the securities. The $\$ 2$ is the margin the MMMF requires to protect against the potential cost derived from selling the securities on the market, if the dealer fails to repurchase them at the maturity of the contract. It is also possible, although more rare, for a haircut to be applied by the securities dealer. This occurs when there is the potential for a rise in the value of the pledged collateral. In such a situation, a securities dealer would, for example, pledge a security worth $\$ 98$ and receive $\$ 100$ in loans. ${ }^{33}$

Regarding maturity, repo transactions are generally either overnight repos or term repos. Overnight repos represent the majority of the US repo market and are generally open repos, which means that they are automatically and implicitly renewed - technically rolled over - until a party decides to terminate them and exit the deal. On the other hand, term repos - traded more often on the European markets - have a maturity that can last from a few days to three months.

In conclusion, looking at the deal from the dealer's perspective - the borrower's side - we have a traditional repo, namely a sale and repurchase agreement. If we take the stand of the MMMF - the lender's side - we have a socalled reverse repo, or purchase and resale agreement. Thus, depending on the leg of the transaction one looks at, one can have both a repo and a reverse repo, as every repo is a reverse repo and vice versa. ${ }^{34} \mathrm{~A}$ more detailed analysis of repos follows in Section III.

${ }^{33}$ Id. at 321.

${ }^{34} \mathrm{Id}$. 


\section{THE REPO MARKET AND THE FINANCIAL SYSTEM}

The repo market is a large market and an essential source of liquidity for the financial system. Little attention, however, has been given to it in the regulatory and legislative spheres. In this section, I will sketch an overview of the repo market's evolution and structure in the US - with a parallel overview of the EU scenario - that focuses on a few infrastructural aspects. I will next address transparency in the repo market by offering some data on its size. (Data in this field have typically been fragmented: only in the last ten years have data on the repo market been tentatively collected. However, these data provide only a partial, incomplete sense of the market's real dimensions.) Finally, I will link the repo market to the financial crisis. I will study the cases of four financial institutions Countrywide Securities, Bear Stearns, Lehman Brothers, and Reserve Primary Fund - that significantly relied on the repo market to fund their short-term positions. When the repo market froze, they were its victims.

\section{A. THE REPO MARKET: DEVELOPMENT AND DIMENSION}

\section{How has the repo market developed?}

The repo market originally developed in an OTC scenario, in which buyers and sellers bilaterally agreed to conclude deals. Alongside the bilateral OTC market, which still constitutes part of the backbone of the whole repo market, the market has evolved through two additional paths: the so-called "tri-party model" and the "held-in-custody model". ${ }^{35}$ In the OTC scenario, repos are privately negotiated and concluded bilaterally by financial institutions without the direct involvement of any intermediaries. Lenders and borrowers mutually agree on the terms of the transaction; the borrower transfers the collateral to the lender, who then transfers the money and becomes responsible for holding the collateral until the moment the transaction matures and reverses.

The tri-party repo, on the other hand, envisages the involvement of an independent third party in the deal. The counterparties of the contract enter into a tripartite agreement with an intermediary clearing bank (in the US the two clearing banks active in the tri-party repo market are JP Morgan Chase ${ }^{36}$ and Bank of New York Mellon ${ }^{37}$ ), which acts as agent and administers the transaction by providing

\footnotetext{
35 The repo market developed both in the US and the EU, keeping very divergent market characteristics in each jurisdiction. In addition to the differences between the structural and operational characteristics of the US and EU repo markets, the two markets also present peculiarities when referring to the contractual structure of repos. See for example the difference in the average maturity of the contracts and the different legal treatment of the transfer of collateral and bankruptcy regimes, for a more detailed analysis see Section III.

36 See https://www.jpmorgan.com/pages/jpmorgan/is/products/clearing.

37 See https://www.bnymellon.com/us/en/what-we-do/solutions/index.jsp\#!filter/brokerdealerservices/us-triparty-repo-infrastructure-reform.
} 
post-trading services - i.e., the selection, market-to-market, transfer, substitution, custody, and management of the collateral, as well as the payment and settlement of the cash-related legs of the deal. ${ }^{38}$ Although the concept of "clearing" might lead to the conclusion that the clearing bank becomes a party to the transaction, by novating the contract and thus becoming the buyer for the seller and the seller for the buyer, the clearing bank does not do so in a tri-party repo contract. Rather, it simply acts as an agent for the parties to a bilateral transaction without becoming a party to the deal.

In contrast, the held-in-custody repo was a contractual mechanism that developed in the 1990s in the government securities repo market. Nowadays, it is less commonly used. In this contractual structure, rather than transferring the securities to the lender, the repo borrower holds them "in custody" at a specific account for the duration of the contract. This mechanism, however, is potentially less stable than the tri-party repo, since in the event that the borrower defaults, the lender will not be in possession of the collateral to cover its exposure.

To provide a complete global overview, we need to look at both the EU and US repo markets: when combined, they represent more than $70 \%$ of the global repo market.

The EU repo market is divided into three main segments. The first is an OTC repo market, which represents roughly half of the whole EU market. The second is an EU tri-party market, which accounts for one-fifth of the whole market and in which five main financial entities (Clearstream Luxembourg, ${ }^{39}$ Euroclear, ${ }^{40}$ Bank of New York Mellon, ${ }^{41}$ JP Morgan Chase, ${ }^{42}$ and SIX ${ }^{43}$ ) act as clearing agents. The third is characterized by anonymous electronic trading via voice brokers and Automatic Trading Systems (ATS), in which repos are centrally cleared through CCPs such as LCH.Clearnet in the United Kingdom, ${ }^{44}$ LCH.Clearnet SA in France, Eurex Clearing in Germany, ${ }^{45}$ CC\&G in Italy, ${ }^{46}$ and MEFF in Spain. ${ }^{47}$

\footnotetext{
38 See ICMA, supra note 30, at 19-20.

39 See http://www.clearstream.com/clearstream-en/products-and-services/global-securitiesfinancing/global-liquidity-hub-icsd-services/triparty-collateral-services---cmax-/repo--1-/triparty-repo (last accessed June 23, 2015).

40 See https://www.euroclear.com/en.html (last accessed June 23, 2015).

41 See https://www.bnymellon.com/us/en/what-we-do/solutions/index.jsp\#!/us/brokerdealer-services (last accessed June 23, 2015).

${ }^{42}$ See https://www.jpmorgan.com/pages/jpmorgan/is/products/clearing/bds (last accessed June 23, 2015).

${ }^{43}$ See http://www.six-securities-services.com/en/home/securities-finance/repo.html (last accessed June 23, 2015).

${ }^{44}$ See http://www.lchclearnet.com/en/asset-classes/fixed-income (last accessed June 23, 2015).

${ }^{45}$ Eurex Clearing is owned by Deutsche Borse AG; see http://www.eurexclearing.com/clearingen/cleared-markets/eurex-repo (last accessed June 23, 2015).

${ }^{46} \mathrm{CC} \& \mathrm{G}$ is the Cassa di Compensazione e Garanzia, which is part of the London Stick Exchange group; see http://www.lseg.com/post-trade-services/ccp-services/ccg/products-and-services (last accessed June $23,2015)$.

${ }^{47}$ MEFF stands for Mercado Español de Futuros Financieros; see http://www.meff.es/aspx/Comun/Pagina.aspx?11=Repo\&f=Home\&id=ing (last accessed June 23, 2015).
} 
In contrast to a clearing bank in the tri-party repo market, a CCP is a party to the transaction. Once the lender and the borrower agree on the terms of the repo, they register with a CCP, which novates the contract and becomes the buyer to the seller and the seller to the buyer. ${ }^{48}$ Through the novation of the original agreed-upon repo, the ССР becomes the counterparty of each of the original parties, which then rely on the CCP for the performance of the contract.

\section{How big is the repo market? Data from the EU and the US}

While on the one hand, we know how and in what directions the repo market has developed, on the other, we lack precise and uniform information about the actual size of the repo market. Industry-driven initiatives make the European and British repo markets slightly more transparent than the American one, ${ }^{49}$ for which the data set is incomplete. In the section, I provide an estimate - though necessarily incomplete - of the size of the US repo market, focusing on the market movements in the years following the Crisis.

In Europe, the ICMA European Repo Council - the industry forum for repo dealers in the EU - has been collecting voluntary semi-annual data on the European repo market since 2001.50 Its last survey, which was published in June 2015,51 calculated the total gross value of outstanding repo contracts in the repo dealers' books to be $\$ 6.345$ trillion. ${ }^{52}$ This represents an increase from the $\$ 6.034$ trillion registered during the "hot semester" of the financial crisis (fall and winter 2008), 53 but a significant decrease from the $\$ 10.121$ trillion reported in June 2008. ${ }^{54}$ The EU repo market had almost doubled in size in the six years prior to the Crisis. ${ }^{55}$

\footnotetext{
48 In the repo scenario, the CCP becomes the lender to the borrower and the borrower to the lender.

49 See http://www.icmagroup.org/Regulatory-Policy-and-Market-Practice/short-term-markets/RepoMarkets/repo/ (last access June 23, 2015).

50 'The values measured by the survey are gross figures, which mean they have not been adjusted for the double counting of the same transactions between pairs of survey participants. However, a study [...] suggested that the problem of double-counting was not very significant.' $I d$. at 9 . Moreover, the values do not include the amount of repo transactions concluded with central banks as part of monetary policy operations. See id.

51 See ICMA, ICMA European repo market survey number 29 conducted June 2015, available at http://www.icmagroup.org/Regulatory-Policy-and-Market-Practice/short-term-markets/RepoMarkets/repo/latest/.

52 The original amount reported is EUR 5,612 billion, see id. at 8. To convert the amount in EU euro to dollar, I applied the historic exchange rate EUR-\$ reported by the Fed

(http://www.federalreserve.gov/releases/h10/hist/dat00_eu.htm) at the day the data were collected.

${ }^{53}$ The original amount reported is EUR 6,504 billion, see ICMA, supra note 51, at 8.

54 The original amount reported is EUR 4,633 billion, $i d$. at 8 .

${ }^{55}$ If however, we look at the nominal amount in EUR, the EU repo market had its pick in June 2007, reaching EUR 6,775, and plummeting to its lowest point in December 2007, with EUR 4,633 billion, $i d$. at 8 .
} 
The EU repo market size in trillions $(\$)^{56}$

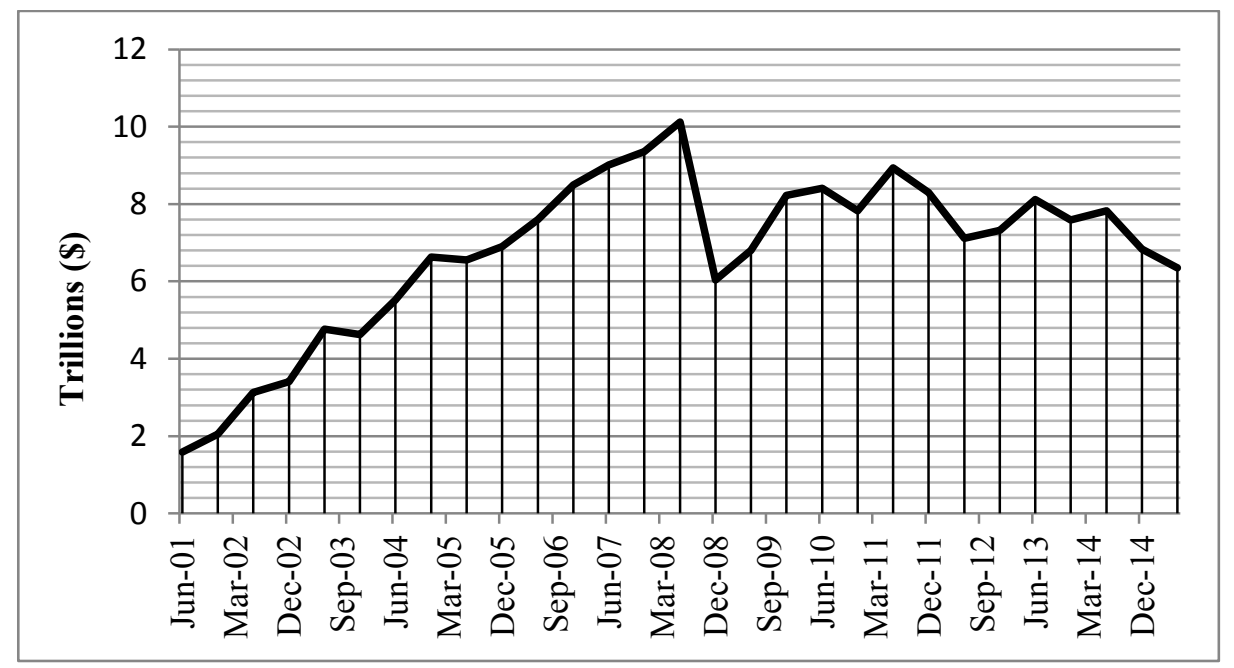

By breaking up the aggregated data, the survey shows that more than $57 \%$ of European repos are traded OTC and are direct bilateral or tri-party repos, with the latter accounting only for $10 \%$ of the market. On the other hand, more than $31 \%$ of outstanding repo transactions are electronically traded on ATS in Europe, ${ }^{57}$ with the remaining portion of transactions concluded via voice brokers, and $30 \%$ of all EU repos are centrally cleared through CCPs. ${ }^{58}$

Looking at the composition of the collateral used in tri-party repo transactions, we see that government securities (including those issued by public agencies and sub-national governments) account for roughly $50 \%$ of the collateral, and that $77 \%$ of those are EU-originated securities..$^{59}$ In terms of maturity, onequarter of EU repos are overnight transactions; approximately $30 \%$ have a maturity of one month or less; and the remaining have up to a year or more of open repo (i.e., repo with no fixed maturity that can be closed at will). ${ }^{60}$

Finally, the annual Eurozone money market data survey, published by the European Central Bank (ECB), ${ }^{61}$ gathers information on the development of the Eurozone money market, excluding the British and Swiss markets. These data show that in the Eurozone repo market, centrally cleared repo transactions account for more than $66 \%$ of the total secured market, with tri-party repos limited to $9 \%$.

\footnotetext{
56 See ICMA, supra note 51.

57 The most common electronic trading platforms for repos in Europe are BrokerTec (http:/ / www.brokertec.com/, last accessed June 23, 2015), Eurex Repo

(http://www.eurexrepo.com/repo-en/, last accessed June 23, 2015), and MTS

(http://www.mtsmarkets.com/Products/MTS-Repo, last accessed June 23, 2015).

58 See ICMA, supra note 30, at 25.

59 See ICMA, supra note 51, at 15-18.

${ }^{60} \mathrm{Id}$.

61 See ECB, Euro Money Market Survey (Oct. 2014), available at

https://www.ecb.europa.eu/stats/money/mmss/html/index.en.html.
} 
At first glance, the European repo market seems to be characterized by the active presence of financial market infrastructure. Repo transactions are largely traded on electronic venues and then centrally cleared via CCPs. The tri-party segment of the repo market is limited, and competition among clearing services is fostered by the presence of five main tri-party agents. ${ }^{62}$

Sketching a picture of the European repo market, even a "guesstimate", is a useful exercise for the purpose of better understanding and evaluating the US market. As mentioned earlier, the US repo market has structurally developed along two main paths: the OTC bilateral market and the tri-party market. In contrast to the EU scenario, however, until very recently there were almost no private industry-driven initiatives to collect data on the actual size of the repo market. ${ }^{63}$ The lack of comprehensive, detailed data on the repo market was clear during and in the immediate aftermath of the Crisis, which revealed significant data gaps in the public regulatory and supervisory arenas. ${ }^{64}$ The only publicly available data on repos were - and to some extent still are - collected by the Fed and reflect the number of financing arrangements of government securities dealers using repurchase and reverse repurchase agreements. ${ }^{65}$

With regard to the US bilateral repo market, because of the exclusive operation in the OTC framework and the lack of financial infrastructure or market utility operating in this area, there is little or no information on its actual size. In July 2014, researchers from the NY Fed - stressing the importance of having data on the repo market - published a study that presents an estimate of the size and composition of the US bilateral repo market. ${ }^{66}$ Beginning with the data submitted by primary dealers ${ }^{67}$ on their total repo activities, the NY Fed researchers took that data - organized according to collateral type - and subtracted from it the activity of the tri-party repo market. From this calculation, they obtained an estimate of the amount of collateral financed in the bilateral repo market, which came to $\$ 1.897$ trillion. ${ }^{68}$ Notably, this study shows that as of October 8, 2014, US

\footnotetext{
62 See ICMA, supra note 51, at 15-18.

${ }^{63}$ The Securities Industry and Financial Markets Association (SIFMA) has published aggregated data on the repo market since mid-2010; see http://www.sifma.org/research/statistics.aspx.

${ }^{64}$ See Adam Copeland et al., Mapping and Sizing the U.S. Repo Market, LiberTy STREET EconOMics, (June 25, 2012, 7:00 AM), http://libertystreeteconomics.newyorkfed.org/2012/06/mapping-and-sizing-the-usrepo-market.html\#.VZ_aub3D_cs.

65 These data are reported weekly by primary dealers using forms FR 2004A/B/C; the aggregated data are available at http://www.newyorkfed.org/banking/reportingforms/FR_2004A_B_C.html (last accessed July 6, 2015)

66 See Adam Copeland et al., Lifting the Veil on the U.S. Bilateral Repo Market, LiberTy STREET ECONOMICS, (July 09, 2014, 7:00 AM), http://libertystreeteconomics.newyorkfed.org/2014/07/lifting-the-veil-on-theus-bilateral-repo-market.html\#.VZ7X5r3D_cs.

${ }^{67}$ Primary dealers are banks and broker-dealers that may trade in US government securities directly with the NY Fed and which serve as counterparties of the NY Fed in tis implementation of monetary policy; see Primary Dealers List at http:/ / www.ny.frb.org/markets/pridealers_current.html (last access, Oct. 5, 2015).

${ }^{68}$ In order to produce this estimate, the authors took the FR2004 data on primary dealer activities in repo (these forms are submitted weekly by all primary dealers and reflect their market activity in all collateral classes; these data are confidential and not publicly available); subtracted from the total amount the
} 
Treasury securities accounted for almost $80 \%$ of the collateral posted in bilateral repos, while accounting for only a little over $40 \%$ of tri-party repos. Official statistics on the overall size of the pre-Crisis repo market are not available; however, in one of their seminal works, Gary Gorton and Andrew Metrick approximated the US repo market during the peak of the crisis at $\$ 10-\$ 12$ trillion - a sum that made it roughly the same size as the $\$ 10$ trillion US banking system at that time. ${ }^{69}$ This figure could, however, include a double counting of repo and reverse repo transactions.

There are a few data collection mechanisms currently operating in the US; however, the picture that they provide to regulators and participants is incomplete and often confusing. In trying to map the sources of data on the repo market, we see quite an intricate scenario. The Fed publishes statistical data on the flow of funds (the aggregate assets and liabilities for financial and non-financial sectors), which reflect information on repos and federal funds. The Financial Stability Oversight Council (FSOC) annually provides statistics on the total size of tri-party repo transactions concluded by primary dealers..$^{70}$ Only in the last five years has the NY Fed - together with the Tri-Party Repo Infrastructure Reform Task Force $^{71}$ - set up a statistical dataset of the monthly market value of tri-party repos in the US, which reflects the value of the "entire population" of repo transactions for which the two clearing banks serve as agents. ${ }^{72}$ These statistics offer disaggregated data by collateral used in the transaction and provide information on the haircut applied to the collateral..$^{73}$ On the market side, SIFMA collects and publishes updated monthly data on the tri-party repo market's size, with additional aggregated data on the collateral most widely used in the market. ${ }^{74}$ The last available survey, as of June 2015, quantifies the US tri-party repo market at $\$ 1.583$

trillion. Of all the trades, $40.1 \%$ had US Treasury securities as collateral, $36.4 \%$ had agencies securities, and the remaining $23.5 \%$ had equity and other securities.

\footnotetext{
amount of tri-party repo funding (data on tri-party repo funding are available in aggregated form and reflect the whole market size - the authors adjusted that number, extrapolating only the tri-party repo activity of the primary dealers, on the assumption that primary dealer make up a little less than $80 \%$ of all repos in the US); and then calculated the amount of funds received. See Copeland et al., supra note 66. 69 See Gorton \& Metrick, Securitized Banking and the Run on the Repo, supra note 7, at 433.

70 See FSOC, Annual Report 2015, available at http://www.treasury.gov/initiatives/fsoc/studiesreports/Documents/2015\%20FSOC\%20Annual\%20Report.pdf.

${ }_{71}$ The Tri-Party Repo Infrastructure Reform Task Force is an industry private-sector body set up in the aftermath of the Crisis under the auspices of the Payments Risk Committee and sponsored by the NY Fed, with the task of addressing the weakness of the repo market. The Task Force includes representatives from multiple types of market participants in the tri-party repo market - clearing banks, dealers, investors, hedge funds, market utilities, and industry groups. For more information see http://www.newyorkfed.org/tripartyrepo/.

72 See Explanatory Notes to the Summary Statistics for the U.S. Tri-Party Repo Market, available at http://www.newyorkfed.org/tripartyrepo/pdf/explanatory_notes.pdf (last access, July 7, 2015).

73 See NY Fed, Tri-Party Repo Infrastructure Reform, available at

http://www.newyorkfed.org/banking/tpr_infr_reform.html.

74 See SIFMA, US GCF Repo Index, Tri-party Repo, and Primary Dealer Financing (Repo/Reverse

Repo), available at http://www.sifma.org/research/statistics.aspx.
} 
A growing but still relatively small segment of the US repo market is the General Collateral Finance (GCF) repo market. ${ }^{75}$ Introduced in 1998 by the Fixed Income Clearing Corporation (FICC), a subsidiary of the DTCC, to reduce transaction costs for securities dealers in the inter-dealers repo market, GCF repos are standardized repo transactions. They are anonymously traded through interdealer brokers and centrally cleared by the FICC, which operates as a central counterparty. By acting as a CCP, the FICC delivers the cash to the borrower and collects and manages the collateral for the lender. A peculiarity of GCF repos is the fact that they use high-quality securities as collateral for deals. According to the latest data collected by the NY Fed, the nominal value of GCF repos netted and traded as of June 2015 amounted to $\$ 584.43$ billion, $40 \%$ of which is represented by overnight repo and $60 \%$ by term repo. Looking at the activity of FICC, the total amount of cash provided to borrowers amounted to $\$ 140.8$ billion, with $\$ 178.7$ billion in securities received as collateral.

\section{The US repo market size in trillions $(\$)^{76}$}

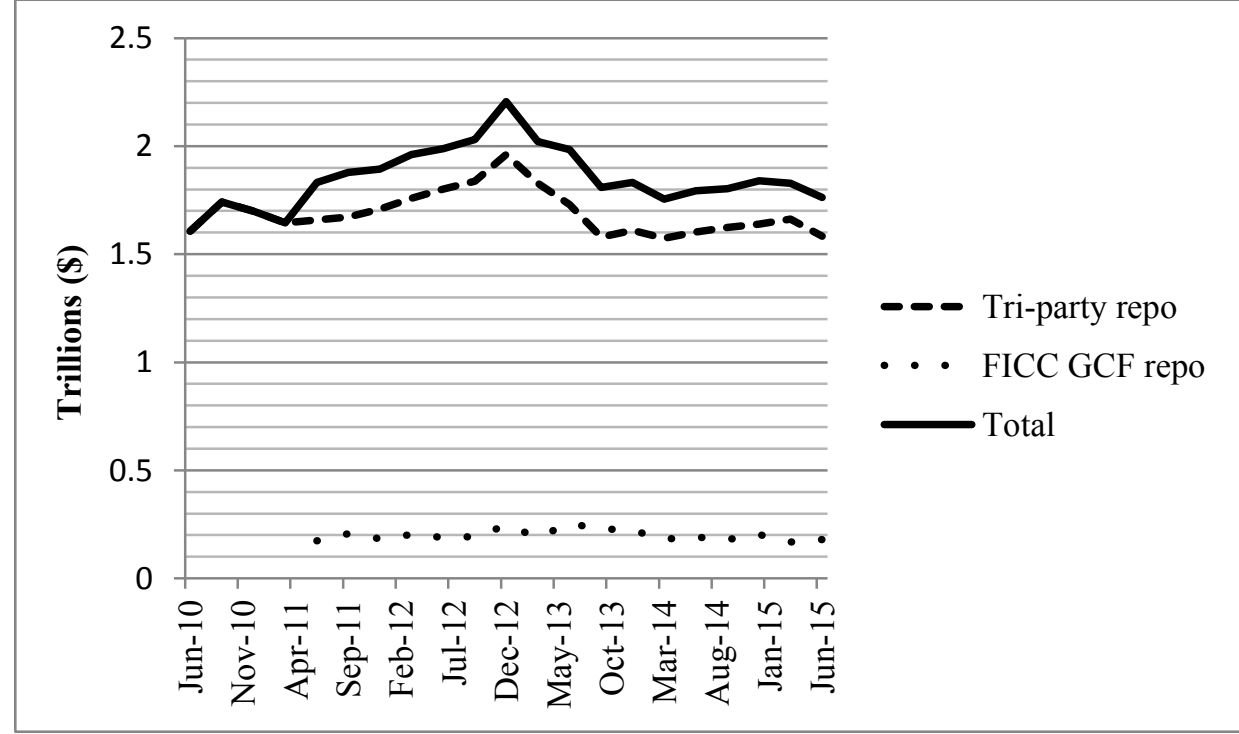

In summary: on the basis of the data collected, we can estimate the current total value of the US repo market to be between $\$ 3.5$ and $\$ 4$ trillion. ${ }^{77}$ This number is simply an approximation based on the fragmented data currently

\footnotetext{
${ }^{75}$ A GCF repo is a repo transaction that refers to a range of assets - generally high-quality collateral that are accepted as collateral by the majority of intermediaries in the repo market.

See ICMA, supra note 58, at 11.

76 See NY Fed, supra note 73.

77 See Copeland, supra note 66; Victoria Baklanova, Repo and Securities Lending: Improving Transparency with Better Data, Office of financial Research Brief Series, 15-03 (Apr. 23, 2015), available at http://financialresearch.gov/briefs/ files/OFRbr-2015-03-repo-sec-lending.pdf.
} 
publicly available. What can be clearly stated is that the repo market is relevant to the financial market, and, as such, it deserves serious analytical and critical analysis.

\section{B. THE 2007-2009 FINANCIAL CRISIS: WHAT ROLE DID THE REPO MARKET PLAY AND HOW WAS IT AFFECTED?}

The general narrative on the causes of the Crisis and its systemic propagation mainly includes the real estate asset bubble, the boom in the subprime mortgage market, the exponential growth of securitization and debt-finance structured products (collateralized debt obligations, asset back securities, and mortgage back securities), and the explosion in use of OTC derivatives such as credit default swaps. ${ }^{78}$ Little attention, however, has been paid to the repo market, which is relatively small when compared to the hundred trillion-dollar OTC derivatives market. ${ }^{79}$

If the financial market were an engine, the repo market - which has grown rapidly since the early $2000 \mathrm{~s}^{80}$ - would be its transmission belt. Yet, as with engines, people start looking at internal mechanisms only when the car stops running. In this case, private and public market actors began to realize the importance of the repo market only when it stopped working properly, i.e., when a liquidity crunch was already happening.

\section{Countrywide Securities: The first cracks in the repo building}

The first fissures in the repo market occurred in the summer of 2007, when Countrywide Securities (Countrywide) showed alarming signs of structural fragility. ${ }^{81}$ As former Treasury Secretary Timothy Geithner stated: 'Countrywide wasn't on [the] radar screen [of the US Treasury] until shortly before the night of August 15, when it nearly paralyzed the entire system.'82 That day, the largest subprime mortgage lender in the US revealed the fragility of its funding structure. ${ }^{83}$ The firm relied heavily on 'unstable, runnable short-term funding. The firm raised much of its operating cash by issuing "commercial paper," [... and] also financed itself through a complex market known as "tri-party repo." 84 That

\footnotetext{
${ }^{78}$ For a critical review on a few relevant pieces of the post-crisis literature on the Crisis, Adam J. Levitin, The Politics of Financial Regulation and the Regulation of Financial Politics: A Review Essay - Reform efforts need to focus on taming politics, 127 HARV. L. REV. 1991 (2014).

${ }^{79}$ Statistics from the Bank for International Settlement set the OTC derivatives market to approximately $\$ 670$ trillion in gross market value; see http://www.bis.org/statistics/derstats.htm.

80 See Peter Hördahl and Michael R. King, Developments in Repo Markets During the Financial Turmoil, 37 BANK OF INT'L SETTLEMENT Q. REV. 37 (2008) arguing that 'repo markets have doubled in size since 2002 , with gross amount outstanding at yearend 2007 of roughly $\$ 10$ trillion in each of the Us and euro repo markets, and another $\$ 1$ trillion in the UK repo market.'

81 See CRISIS INQUIRY REPORT, supra note 16, at 248-250, which analyses Countrywide's liquidity crisis and incapacity to use mortgage securities as collateral in repo transactions.

82 Timothy F. Geithner, supra note 3.

$83 \mathrm{Id}$. at 122.

${ }^{84} \mathrm{Id}$. at 123 .
} 
night, once the market sensed Countrywide's structural vulnerabilities, ${ }^{85}$ some of its lenders refused to roll over its commercial papers - causing its most important source of cash to dry up. Furthermore, Bank of New York Mellon (BNYM), the firm's tri-party repo clearing bank, threatened 'not to "unwind" the firm's $\$ 45$ billion repo book the next morning, ${ }^{\prime} 86$ warning Countrywide's cash lenders about the firm's potential and imminent risk of default on its repo transactions, as well as the consequent transfer of securities pledged as collateral. A decision on the part of BNYM not to "unwind" Countrywide's repo portfolio would have triggered four main consequences in the market: (1) loss of confidence in Countrywide as a financial institution; (2) loss of confidence in other similar institutions that financed their short-term liquidity by repoing the same classes of securities; (3) loss of confidence in tri-party repo market mechanisms; and (4) risk of a "fire sale" of the pledged assets as cash lenders tried to realize the value of the collateral with sales. As Secretary Geithner described in the memoir of his time at the Treasury Department, the night of August 15, 2007 was a night of intense negotiations between BNYM, Countrywide executives, and officials from the Treasury and the Fed. Negotiations terminated with BNYM agreeing to unwind Countrywide's repo portfolio, provided that the pledged collateral were upgraded. ${ }^{87}$

This episode, despite occurring during the very early stages of the financial crisis, 'revealed $[\ldots]$ how dependent the entire financial system [was] on short term financial funding agreement[s]. [...] [A]nd it showed that this fragility extended even to the secured funding markets - where lending decisions [...][are] based on the borrower's collateral rather than just its underlying creditworthiness' 88

\section{Bear Stearns, Lehman Brothers, and the collapse: The repo market freeze and the Fed's response}

In the spring and fall of 2008, Bear Stearns and Lehman Brothers were the two main victims of over-reliance on the repo market as a source of operational liquidity. As described above, an effective repo market requires high reputational standards and confidence among market participants, highly liquid and safe assets pledged as collateral by borrowers, and the presence of reliable operational mechanisms. When one of these elements is missing, the whole structure falters. With Bear Stearns and Lehman Brothers relying heavily on overnight repo financing in order to operate, ${ }^{89}$ two of those elements (high-quality collateral and

\footnotetext{
85 See id. at 124-125: 'on the $15^{\text {th }}$, with the price of Countrywide's debt against default up eightfold in just a month, a previously bullish Merrill Lynch analyst issued a report titled "Liquidity is the Achilles' Heel," warning that cash pressures could force countrywide into bankruptcy.'

86 Id. at 124.

${ }^{87} \mathrm{Id}$. at 126. Add a sentence/comment on the similitude with public-private approach in the rescue of

LTCM lead by the government but put in place by private institutions.

88 Id. at 127.

89 Id. at 161 .
} 
reliable operational mechanisms) were missing. ${ }^{90}$ This then induced repo lenders to question the financial stability of these institutions and doubt whether they should continue providing them with liquidity. As mentioned above, the US repo market expanded its reach to more volatile, less liquid securities (e.g., CDO, ABS, and MBS) rather than focusing on US government securities. However, as the subprime mortgage market and its related structured products ${ }^{91}$ began deteriorating, the US repo market started to face serious problems. Following the burst of the housing bubble and the subprime crisis, first, the value and liquidity of the pledged collateral - CDO, MBS, and ABS - plunged. Then, once the repo counterparties of the two firms became aware of the exposure of these institutions to short-term financing and structured financial products, they began to cast doubt on their financial stability, reliability, and operational capacity. ${ }^{92}$ These two events, in combination with the heightened sense of insecurity and loss of confidence among market participants, resulted in a drain of the liquidity supply in the repo market. ${ }^{93}$

Lenders became unwilling to enter into transactions with risky counterparties and, more seriously, they stopped rolling over their repo financing to Bear Stearns and Lehman Brothers. While during the first stages of the Crisis repo lenders were still willing to provide repo financing on Treasury bills, when the panic spread they refused to roll over repo transactions backed by those bills. As the number and type of securities that could be accepted as collateral by repo lenders decreased, and as market participants began to question the liquidity and reliability of Treasury bills, the repo market froze. One of the proximate causes of the entire Crisis was the inability of Lehman Brothers to roll over its overnight securities loans through the repo market, along with its inability to borrow cash to finance it securities inventory.

\footnotetext{
90 See Skeel, supra note 4, at 31-33, 60-61; Gillian Tett, Fool's Gold - The Inside Story of J.P. Morgan and How Wall Street Greet Corrupted Its Bold Dream and Created a Financial Catastrophe (2010), "Bear's real Achilles' heel was its funding base", $i d$. at 217.

${ }^{91}$ Structure products are synthetic investment instruments in which the payoff is connected to the performance of specific assets or indexes.

92 For example, see FINANCIAL CRISIS INQUIRY REPORT, supra note 81, at 284, 288, which discusses the unwillingness of several MMMFs to roll over Bear in the run-up to Bear's liquidity crisis and sale to JPMC.

93 See Geithner, supra note 3; in describing the Bear situation, Secretary Geithner said: 'the real lesson of Bear was that in a world of extreme leverage and short term financing, confidence can vanish in a heartbeat, and liquidity along with it.'
} 


\section{Lehman Brother's Tri-Party Repo Book by Collateral Type ${ }^{94}$}

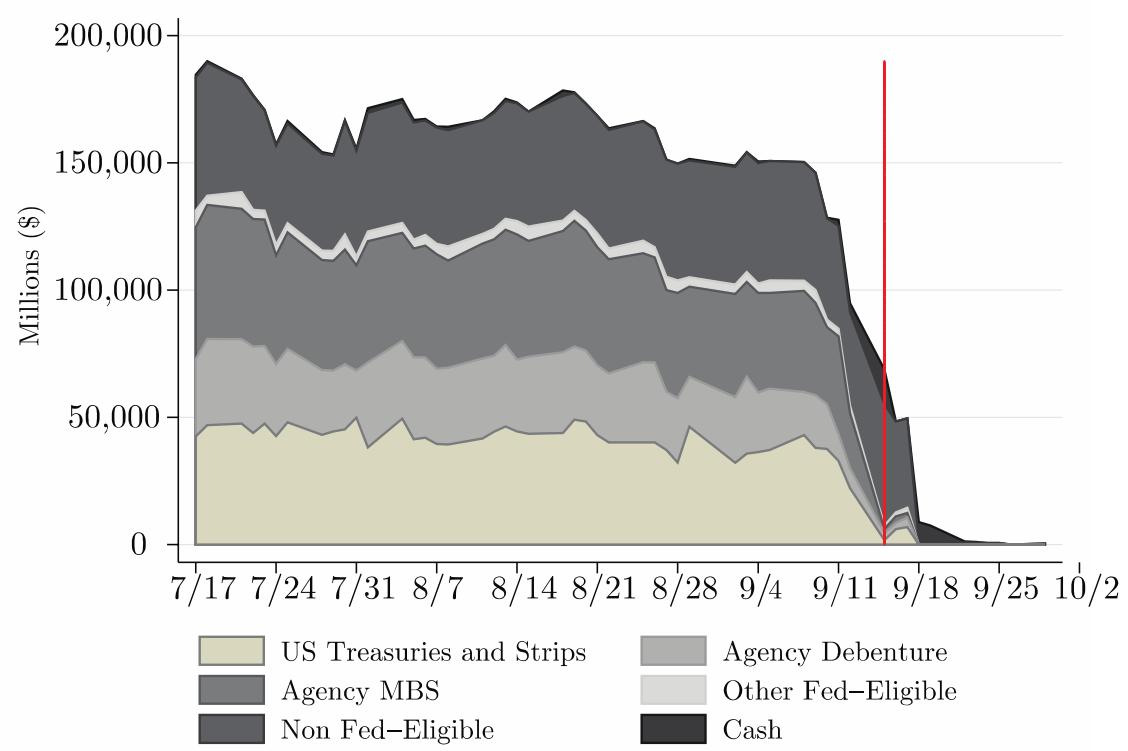

When the run on the repo market occurred, the main victims were the repo dealers who suddenly came up short in liquidity with which to finance their investments and business operations. After an initial liquidity injection of $\$ 25$ billion by the NY Fed, ${ }^{95}$ Bear Stearns was sold on March 18, 2008 and merged with JP Morgan Chase - its main repo clearing bank - in a deal assisted and sponsored by the Fed. ${ }^{96}$ Lehman Brothers filed for Chapter 11 bankruptcy protection on September 15, 2008.97 Lehman Brothers, which was burdened by more than $\$ 600$ billion in debt, was the largest bankruptcy filing in US history. ${ }^{98}$

\footnotetext{
${ }^{94}$ Copeland et al., supra note 64 at 57.

95 See Andrew Ross Sorkin, JP Morgan Pays $\$ 2$ a Share for Bear Stearns, March 17, 2009, available at http://www.nytimes.com/2008/03/17/business/17bear.html?_r=0.

96 See Yalman Onaran, Fed Aided Bear Stearns as Firm Faced Chapter 11, Bernanke Says, April 2, 2008 13:20 EDT, available at

http://www.bloomberg.com/apps/news?pid=newsarchive\&refer=worldwide\&sid=a7coicThgaEE. 97 See Andrew Ross Sorkin, The Race to Save Lehman Brother, N.Y. Times (Oct. 20, 2009) available at http://www.nytimes.com/2009/10/20/business/economy/20sorkin.html?pagewanted=all. 98 See Sam Mamudi, Lehman folds with record $\$ 613$ billion debt, $($ Sept 15, 2008) available at http://www.marketwatch.com/story/lehman-folds-with-record-613-billion-debt?siteid=rss. The massive post-Crisis Lehman litigation revealed a peculiar use of repos other than their traditional lending purpose. Literally following the legal definition of a repo as a sale and repurchase agreement, and spotting a flaw in the accounting rules, Lehman set up a set of so-called "Repo 105" transactions. In a traditional repo, the lender generally applies a haircut on the transferred collateral to reflect and compensate for the potential liquidation, transactional, and operational costs. Such a haircut, however, is conventionally in the range of a maximum of $3 \%$ of the value of the collateral. In the Repo 105, Lehman was posting collateral with a high enough haircut that the transaction was considered - in terms of accounting rules - a real sale of assets rather than a loan. Thus, Lehman was able to sell out ("hide") a significant amount of its liabilities from its balance sheets ( $\$ 50$ billion worth of risky structured products) just by entering into 105 repos. See Michael Bridge \& Jo Braithwaite, Private Law and Financial Crises, 13(2) J. OF CORP. L. STUD. 361 (2013).
} 
After the collapse of two of the largest broker-dealers on Wall Street, repo lenders were trapped with a significant amount of collateral that was supposed to be repurchased by the defaulted repo borrowers. As repo lenders needed to refinance their cash accounts and cover their exposure on the defaulted repo transactions, they tried to liquidate the pledged assets, flooding the market with securities. In this distressed market scenario, as repo lenders tried to recoup any value they could from their already devaluated collateral, they heavily discounted the price of the securities they were holding. This "fire sale" 99 triggered further panic in the markets, with asset prices caught in a downward spiral. ${ }^{100}$

A secondhand victim of the "fire sale" in the repo market was Reserve Primary Fund (RPF), one of the largest MMMFs in the US. RPF - which was heavily exposed in Lehman Brothers' commercial papers and which was active in repo market lending - suffered a run of its investors when they became aware of the unsecured exposure to Lehman Brothers and then RPF "broke the buck" the day after Lehman Brothers filed for bankruptcy. ${ }^{101}$ This event triggered a run on other MMMFs, which consequently had to drastically reduce the amount of cash outflows invested in the repo market in order to meet their clients' demands.

Thus, the repo market was not only affected by the financial crisis, but also ended up being a propagative mechanism that seriously exacerbated that crisis. As one of the main liquidity pipes in the financial system, once it froze, the entire market suffered the consequences. As the value of the assets pledged as collateral in many repo transactions began to decline, repo investors asked for higher haircuts - requiring dealers to post additional collateral - and even refused to roll over their repos at maturity. The spike in the amount of the haircuts requested for many asset classes, ${ }^{102}$ coupled with a market-wide downward spiral in asset prices, made short-term funding too expensive for securities dealers. It also made it too risky and too costly for cash investors. This resulted in a freeze in the repo market, as repo borrowers were not able to borrow anymore and repo lenders were not willing to lend or were more cautious in lending. Only the intervention of the Fed, with its swap programs and liquidity facilities - the Term Securities Lending Facility (TSLF) ${ }^{103}$ and the Primary Dealer Credit Facility (PDCF) 104 - was able to

\footnotetext{
99 "Fire sale" has been defined by Shleifer and Vishny as the forced sale of an asset at a dislocated price; see Andrei Shleifer and Robert W. Vishny, Liquidation Value and Debt Capacity: A Market Equilibrium Approach, 47(4) J. FIN. 1343.

100 See Brian Begalle et al., The Risk, of fire Sales in the Tri-Party Repo Market, NY Fed Staff Report No. 616, May 2013, available at http://www.newyorkfed.org/research/staff_reports/sr616.pdf, at 9.

101 The idea of "breaking the buck" is commonly used in the mutual funds industry to refer to a situation in which a fund's net asset value (NAV) falls below the par value of $\$ 1$. More specifically, since MMMFs offer stable NAV and can at any time redeem their investment/deposit at par value, when the NAV falls below $\$ 1$, MMMFs experience a run. This is what happened to RPF when Lehman filed for bankruptcy. 102 See Gary Gorton \& Andrew Metrick, Haircut, Yale ICF Working Paper No. 09-15 (May 12, 2010), available at http://ssrn.com/abstract $=1447438$.

103 See Michael J. Flemign et al., The Term Securities Lending Facility: Origin, Design, and Effect, 15(2) CurReNT IssUeS IN ECON. AND FIN. 1 (Feb. 2009), available at http://www.newyorkfed.org/research/current_issues/ci15-2.html; Geithner, supra note 82, at 146; information and data on the activity of the TSLF are available at
} 
break the ice inside the repo plumbing and permit liquidity to circulate again through the repo market. Both programs, which were implemented within a week of each other at the height of the Bear Stearns crisis, were temporary measures intended to sustain and promote liquidity in the funding markets and improve the overall performance of the financial system. The Fed decided to intervene both on the collateral supply side - to contain the risk of "fire sales" - and on the cash supply side - to support the liquidity demands of market participants.

The TSLF was a temporary collateral swap facility that promoted liquidity in Treasury bills and other asset markets. The program, established under the Fed's emergency lending power, was open to all primary dealers, allowing them to borrow US Treasury securities by pledging as collateral other securities, such as MBS, agency debt securities, and investment-grade debt securities. ${ }^{105}$ The TSLF successfully attempted to increase the ability of dealers to obtain funding via collateralized financing and to prevent dealers from "fire selling" assets in an illiquid market. 106 Operating as an auction facility, the TSFL offered 'to lend general Treasury collateral against pledges of other fixed-income collateral' on a weekly basis. ${ }^{107}$ The TSLF charged a minimum fee for the performance of this operation ${ }^{108}$ and imposed a haircut on the securities pledged by the dealers in order to protect against counterparty and credit risk.

The other important Fed program, the PDCF, aimed to support the liquidity needs of primary dealers. Established at the NY Fed, the PDCF allowed primary dealers to borrow from the NY Fed on a collateral basis in times of market distress. Simply put, the PDCF provided primary dealers with the same services that the Fed discount window provides to depository institutions, i.e. a backstop source of liquidity. ${ }^{109}$ The PDCF program allowed primary dealers to obtain

http://www.federalreserve.gov/newsevents/reform_tslf.htm, and

http://www.newyorkfed.org/markets/tslf.html.

104 See Tobias Adrian et al., The Federal Reserve' Primary Dealer Credit Facility, 15(4) CuRRENT Issues IN

ECON. AND FIn. 1 (Aug. 2009), available at http://www.newyorkfed.org/research/current_issues/ci15-

4.html; Geithner, supra note 59, at 146; information and data on the activity of the PDCF are available at

http://www.federalreserve.gov/newsevents/reform_pdcf.htm/, and

http://www.newyorkfed.org/markets/pdcf.html.

105 See Fleming et al., supra note 103, at 3.

$106 \mathrm{Id}$.

107 Id. at 5.

108 The fee charged by the TSLF was set at a level somewhat higher than the interest charged for the borrowing of Treasury securities against program-eligible collateral by the private market under normal circumstances; see $i d$. The rationale for this fee was to make the TSLF appealing to dealers only when the markets were in a distressed situation.

109 Ben S. Bernanke, The Federal Reserve and the financial Crisis: Lectures by Ben S. Bernanke 4-6 (2013). Generally on the Fed's Discount Window Lending Programs, see Frequently Asked Questions - Discount Window Lending Programs, FeD. Res. Discount Window \& PAYMENT SYs. Risk, http://www.frbdiscountwindow.org/dwfaqs.cfm?hdrID=14\&dtlID $=75$ (last visited Oct. 3, 2015). The Fed can operate as a lender of last resort via two mechanisms: Section 10B and Section 13(3) of the Federal Reserve Act. Section 10B - 12 U.S.C. $\$ 347 \mathrm{~b}$ - confers the power to the Fed to extend loans to the member banks, what is generally refers to as Discount Window. Section 13(3) - 12 U.S.C. \$343 extends the Fed's power to provide liquidity to entities others than members bank 'in unusual and exigent 
liquidity against any collateral deemed acceptable by clearing banks in the tri-party market, which included MBS, ABS, municipal securities, and investment-grade corporate securities. ${ }^{110}$ The NY Fed charged interest on the amount lent - the socalled "discount rate" - which, in a normal market scenario, would be higher than the overnight repo rate.

Both of the Fed's programs began operations during the worst days of the Bear Stearns crisis and supported the repo market until February 1, 2010, when they were dismantled. The Fed's intervention was crucial in sustaining the liquidity of the financial markets. Operating on the supply side for liquidity and safe collateral, the Fed was able to act as a reliable substitute source of liquidity for the collapsed repo market and to contain the "fire sales" of troubled assets. In this way, the Fed supported investment banks and broker dealers in their funding activities. What made the Fed's intervention necessary was the absence of public safety nets and the inaccessibility of the Fed's discount window mechanisms to investment banks, broker-dealers, and "shadow banking" entities more broadly. ${ }^{111}$

\section{WHAT IS A REPO? LEGAL AND ECONOMIC STRUCTURE}

\section{A. The legal Structure of A REPO: NeITHER A SECURED LOAN NOR SECURITIES LENDING}

A repo is a two-leg bilateral contract in which a sale of securities is coupled with a repurchase agreement. In the first leg of the transaction, the seller transfers securities $^{112}$ to the buyer at a fixed time and at a determined price. The second leg of the deal is a simultaneous agreement whereby the buyer agrees to sell the securities back to the seller and the seller agrees to repurchase them at a future date or on demand. ${ }^{113}$ The difference between the repurchase price and the price originally paid by the buyer is the interest the buyer has to pay in order to borrow

\footnotetext{
circumstances ... [when the entity can prove to be] unable to secure adequate credit accommodations from other banking institutions.'

110 See Adrian, supra note 104, at 3-4, 5.

111 The NY Fed is still operating in the repo market as an active player. The Open Market Trading Desk at the NY Fed 'implements monetary policy for the Federal Reserve System at the behest of the Federal Open Market Committee.' In doing so, the NY Fed uses repo to make collateralized loans to primary dealers; and conversely borrow money from primary dealers via reverse repos. 'Repos and reverse repos are conducted with primary dealers via auction. In a repo, dealers bid on borrowing money versus various types of general collateral. In a reverse repo, dealers offer interest rates at which they would lend money to the Fed versus the Fed's Treasury general collateral, typically Treasury bills.' See N.Y. Fed., Repurchase and Reverse Repurchase Transactions (Aug. 2007), available at

http://www.newyorkfed.org/aboutthefed/fedpoint/fed04.html.

112 Generally, the securities used in a repo transaction are fixed-income financial instruments - such as

Treasury bills, mortgage-backed securities, sovereign bonds, and corporate bonds - but they can also be equities.

113 See Sec. 1, 2012 Global Master Repurchase Agreement.
} 
from the seller. This price differential is expressed in percentage points, and on an annual basis is generally called the "repo rate". ${ }^{114}$

The transferred securities operate as collateral in the transaction and contribute to mitigating the counterparty credit risks borne by the buyer. In fact, upon conclusion of the contract, the buyer acquires the full legal title to the securities. Unless otherwise agreed by the parties, however, the seller maintains the beneficial ownership of the securities, i.e., any income payment generated by the collateral must be returned to the seller. ${ }^{115}$ In the event that the seller defaults and fails to repurchase the securities at the termination date or upon the buyer's demand, the buyer can keep the ownership of the securities and can sell them to cover its exposure on the transaction.

With regard to typical repo transaction maturity, a repo can either be subject to a term or fixed maturity date - typically a short-term, i.e., overnight, transaction - or parties can agree to conclude a so-called "open" or "open-ended" term repo, in which no maturity date is fixed and either party has "on demand" rights to terminate the contract by notifying the counterparty on any date that it finds convenient. If the repo does not have a fixed maturity date or is not open, the repo automatically rolls over every day.

Usually, repos last overnight. They can also be structured with longer maturity as short-dated repos (with weekly or monthly maturity, up to a maximum of three months) or as term repos (a less common variant with annual maturity). A very important aspect of a repo transaction is the right of the parties to extend the duration of the deal by renewing the contract at termination date. Technically, the extension of a repo is called a "rollover", in which parties agree to substitute the matured deal with a new one that can either replicate the previous one or adjust the original contractual terms.

Significantly, the whole repo transaction is built around the transferred securities, which operate as collateral for the stability of the deal. Legally, and because of the structure of the transaction, the transferred securities are simultaneously the object of the contract and its collateral. Furthermore, the contract comprises the right of the buyer to finance its purchase by reversing out the very same received collateral, or "re-hypothecating". In this instance, the buyer pledges the securities in another repo, earning a profit from the gap between the rate of the original repo and that of the reverse repo. Re-hypothecation of collateral is quite common in repo agreements. ${ }^{116}$

A repo's underlying securities are generally high-quality. Although highquality government bonds are the most common collateral on the repo market, there are also corporate bonds, mortgage-backed securities, asset-backed securities, and equities. A repo can be built around two main collateral structures:

114 The repo rate reflects the riskiness of the transaction, the quality of the collateral, the liquidity of the collateral, etc.

115 See Sec. 5, 2012 Global Master Repurchase Agreement.

116 Re-hypothecation is the use of pledged collateral as collateral in a transaction with a third party. 
general collateral repo and special collateral repo. The difference between the two types of repo depends on the type and quality of the underlying security. In a general repo contract, the parties refer to a basket of high-quality liquid assets that can be accepted in the transaction and ease the collateral substitution mechanisms by providing a more diversified set of underlying assets. In a special collateral repo, the parties want a specific asset to be the object of the deal. Whether the parties choose to engage in a general or special collateral repo depends on their goals. If they want to use the contract as a stable and sound financing mechanism, they opt for the general repo; if they need specific securities because of a particular asset's intrinsic characteristics or because of the peculiar financial or investment interests and strategies of the buyer, they opt for the special repo.

The analysis of the type of assets commonly traded in the repo market shows that parties look for securities that pose low counterparty and/or liquidation risks. In addition, when determining the purchase price of the securities, the buyer wants the price to reflect all of the potential risks underlying the transactions. The aggregation of these risks is reflected in the valuation of the securities pledged as collateral. Generally, collateral is commonly valuated below its market value at the time a repo is concluded in order to incorporate and reflect the counterparty risk, operational risk, legal risk, and liquidation risk of the collateral in the event of default. ${ }^{117}$ The spread between the market value of the transferred securities and the purchase price is called the "haircut". 118

A repo can be deconstructed into two sequences: repo and reverse repo. From the standpoint of the securities seller, which borrows the money in the repo market by selling the underlying securities, the transaction is referred to as a "plain repo". In practitioners' jargon, the seller "repos" the securities, or "reverses out" the securities/collateral for repurchase. In a reverse repo, the lender/buyer purchases the borrower's securities for resale and lends the borrower money, thus "reversing in" the securities. ${ }^{119}$ Repo and reverse repo are, therefore, two sides of the same transaction; for each repo there is a specular reverse repo.

Repo transactions are concluded using highly standardized contractual models. The boilerplate repo contract terms have been drafted by the industry association (ICMA) and constitute the two main Master Agreements (MAs). The so-called Repurchases Market Agreement (RMA) privately regulates any US Treasury bill under New York State law. In contrast, the Global Master Repurchase Agreement (GMRA) governs all repos that have other categories of

117 Counterparty risk is the likelihood of default in the payment of the counterparty; operational risk, in the context of collateral evaluation, reflects the cost of managing collateral and margin calling; legal risk is related to the cost and timing of litigating the legal title of the collateral; and liquidation risk is the cost of delays or devaluation from the sale of the assets in case of default.

118 The notions of "haircut" and "initial margin" are substantively identical; they refer to the same tool, but are calculated and expressed using alternative mathematical terms. The haircut is the expression in percentage points of the deduction from the market value of the collateral - e.g., a 5\% haircut on a $\$ 100$ bond (market value) is reflected in a $\$ 95$ purchase price. In contrast, the initial margin represents the market value of the collateral as a percentage of the purchase price - e.g., a collateral with a $105 \%$ market value on the purchase price. See ICMA, supra note 30.

119 See Marcia L. Stigum, Stigum's Money Market (2007). 
underlying securities and generally applies English and Welsh law. The MAs cover all of the essential elements of a deal, provide all the contract term definitions, and contractually regulate all the steps of the transaction: initiation, confirmation and termination, margin and collateral management, income payment, events of default, and applicable law and jurisdiction.

In terms of economic structure and benefits, repos resemble other financial contracts. In terms of their structure and purpose, repos present similarities to both secured lending and securities lending. While similar, however, these financial instruments maintain their peculiarities and differences. While the economic structure of a repo has much in common with a secured/collateralized loan, it differs on the basis of relevant legal elements and economic dynamics. Repo replicates the economic functions of a loan by combining the sale of securities with the contextual repurchase agreement of the same assets. Repos are generally highly standardized transactions that require liquid, high-quality collateral. In a repo transaction, the formal ownership of collateral is transferred from the borrower to the lender, while the beneficial and economic ownership stays with the securities' original owner. A peculiar element of repo contracts that makes them similar to derivatives is their favourable bankruptcy treatment: they are, in fact, exempted from many bankruptcy provisions, such as the automatic stay. ${ }^{120}$

\section{B. THE ECONOMIC FUNCTION OF REPOS: COLLATERALIZED LOANS AND NONDEPOSIT DEPOSITS}

Before moving into an analysis of the repo market's economic functions, it is necessary to sketch a picture of the current major actors in the repo market. While sellers and buyers are often distinct, because the repo market is fluid, financial institutions often play both roles by buying securities and selling them at the same time (the so-called "re-hypothecation" of collateral).

Generally, securities market intermediaries, i.e., broker dealers and leveraged investors such as hedge funds or securities firms, are the sellers/borrowers seeking

\footnotetext{
120 The International Swap and Derivatives Association (ISDA) just recently announced that the 18 largest derivatives dealers have agreed to contractually soften the right of the non-defaulting counterparty to call for an early termination of the contract in a set of specific circumstances - indirectly lightening (even if only for 48 hours) the bankruptcy safe harbour of the exemption from automatic stay. See ISDA, Major Banks Agree to Sign ISDA Resolution Stay Protocol (Oct. 11, 2014), available at http://assets.isda.org/media/de778136/58b5618f.pdf. See Mark Roe, Reforming Repo Rules, Project Syndicate (Dec. 21, 2011), available at http://www.project-syndicate.org/commentary/reforming-reporules; id. End bankruptcy priority for derivatives, repos and swaps, FIN. TIMES, Dec. 16, 2009, available at http://www.ft.com/cms/s/0/16da702e-ea41-11de-aeb6-00144feab49a.html\#axzz3jHUg2J6G; Edward R. Morrison, Mark J. Roe \& Christopher S. Sontchi, Rolling Back, the Repo Safe Harbors, 69 Bus. Law. 1015 (Aug. 2014); Darrell Duffie \& David A. Skeel, A Dialogue on the Costs and Benefits of Automatic Stays for Derivatives and Repurchase Agreements (Mar. 1, 2012). U of Penn, Inst for Law \& Econ Research Paper No. 12-02; Rock Center for Corporate Governance at Stanford University Working Paper No. 108; Stanford University Working Paper No. 108, available at http://ssrn.com/abstract=1982095 (arguing that repos backed by liquid securities should be exempt from automatic stays, and that repos backed by illiquid assets should not be given this safe harbour).
} 
to finance their portfolios and short-term investments. Cash providers/lenders the buyers - are generally MMMFs and other entities with high cash reserves that are risk averse in investment options. A non-extensive list of these players can include commercial banks, insurance firms, corporate treasuries, pension funds, local governments, international financial institutions wishing to invest their foreign reserves, and, more recently, foreign central banks and sovereign wealth funds investing their surplus in foreign reserves. By operating in the internal repo market in order to pursue monetary policies, national central banks often operate on both sides of the market, depending on systemic monetary needs.

Due to their structure and flexibility, repos can perform and facilitate a variety of economic purposes. From the buyer-lender perspective, repos provide a secured form of investment of cash resources. Generally, cash pools have two options: buying government bonds, which is commonly considered a risk-free investment, ${ }^{121}$ or depositing them in deposit accounts at a bank. Neither of these solutions, however, are the most efficient options for cash pools. Government bonds, despite being a secured form of investment, are limited in number and are a scarce resource (and the cash reserves that need to be invested far exceed the availability of Treasury bills and safe government bonds in general). Bank deposits, while potentially unlimited resources, are unsecured investments: deposit accounts are only very partially backed by governments through the deposit insurance mechanism. ${ }^{122}$ The gap between these two possible cash investment options is filled by the repo market, which potentially provides unlimited secured forms of investment. The buyer's cash, which is invested in the purchase of securities, is then returned with accrued interest by the seller at termination.

For the seller-borrower, compared to a traditional secured loan, repos are a cheaper, less risky, more flexible tool for financing. Repo contracts have a lower legal risk and more efficient counterparty risk mechanisms than secured loans. Securities pools can have more plentiful sources of income in the repo market than when they simply hold securities in their accounts or offer them in the securities lending market. Repos can also serve a speculative function; parties can "go short" or "go long" on a security, depending on whether they choose to be the seller of the security or the buyer in a repo.

In all of this, central banks play a special role. Whether they act as buyer or seller, central banks use the repo market as a monetary policy tool to control the

\footnotetext{
121 This statement mainly refers to Treasury bonds issued by the US government or by other stable Western and Eastern governments (including instruments issued by the ECB and European institutions). Treasuries are generally considered risk-free assets on the assumption that they are backed by governments - that governments have access to "unlimited funding" by printing new money and do not fail.

122 In the US, the Federal Deposit Insurance Corporation (FDIC) provides insurance coverage to all deposit accounts - including checking and savings accounts, money market deposit accounts, and certificates of deposit - at a maximum amount of $\$ 250,000$ per depositor, per insured bank, for each account ownership category. See http://www.fdic.gov/deposit/deposits/. In the EU, the depositguarantee scheme covers up to $€ 100,000$, but member states can provide higher levels of protection. See http://ec.europa.eu/internal_market/bank/guarantee/index_en.htm.
} 
amount of liquidity in the financial market. By buying securities, they inject liquidity into the market; by selling securities, they reduce liquidity in the market. ${ }^{123}$

\section{FAILURES IN THE REPO MARKET}

The previous sections analysed the economic and legal structure of repos and looked at how repos performed in and were central to the Crisis. That analysis revealed the structural failures and weaknesses of the repo market. This section, building on those findings, identifies the market failures that necessitate reform in the repo market.

This section is structured in four parts, each of which pinpoints a failure in the repo market. Part A analyses the opacity of the repo market; Part B examines the structural fragilities within the tri-party repo market; Part $C$ assesses the regulatory and supervisory misalignment of the repo market; and Part D focuses on the market's systemic risk, looking at the interconnectedness of market participants and considering how the maturity and liquidity mismatch in repo transactions exacerbates its vulnerability to panic and proneness to run.

\section{A. REPO MARKET OPACITY}

The repo market is opaque: repo data are scarce and unreliable. When the Crisis hit the repo market, no data were available on the size of the OTC bilateral market, and regulators and authorities were completely unaware of its actual size. Similarly, until 2010, there were no publicly available aggregated data on the triparty repo market, ${ }^{124}$ and regulators were only able to quantify ex-post the aggregated volume of repo transactions concluded by NY Fed primary dealers. ${ }^{125}$ Opacity has affected the repo market at a macroprudential and systemic level as well as at a transactional and microprudential level. This opacity fully reflects the nature of the repo market - namely the OTC nature - and it is structurally similar to the situation of the pre-Crisis OTC derivatives market, which was ultimately extensively regulated in the aftermath of the Crisis. A whole segment of the repo market - the OTC bilateral repo segment - is not captured in any statistical analysis, remaining completely opaque. Furthermore, the sample of participants

\footnotetext{
123 The repo market is also critical for secondary market liquidity in Treasuries and other assets.

124 The NY Fed became the first entity to publish aggregated data on the tri-party repo market in mid2010, implementing one of the recommendations published in the Tri-Party Repo Infrastructure Reform White Paper. See NY Fed, Tri-Party Repo Infrastructure Reform - A White Paper, 28 (May 17, 2010), Task Force on Tri-Party Repo Infrastructure, available at http://www.newyorkfed.org/newsevents/news/banking/2010/an100517.html. For the repo market data archives, see NY Fed, Tri-party Repo Statistical Data, available at http://www.newyorkfed.org/banking/tpr_infr_reform_data.html. 125 See supra note 67.
} 
reflected in the NY Fed survey does not accurately reflect the whole US repo market, only the primary dealers. The available data are only historical, providing past information covering a limited period of time. There are no available data on the portfolio sizes, prices, and exposure of market participants.

The SEC and the Fed had both collected data from market participants via regulatory filings, ${ }^{126}$ but had not made them available to the public. In fact, even when they were made public, the data provided a very incomplete picture of the market. Regulators therefore have limited information on the overall exposure and risk connected to the repo market, repo transactions, and repo collateral.

Market participants also operated in a marketplace dominated by information asymmetries. They lacked information on the market's dimensions, the total exposure of their counterparties, the risk underlying transactions, the collateral used in deals, the overall market exposure on individual collateral, and the pricing of transactions. The absence of trading utilities increases the transaction costs for market participants by increasing the cost of pricing the risk underlying the transactions. The public information available is scarce and the private costs to fill these gaps are too high. Contracting parties face difficulties in evaluating counterparty risk, i.e., the risk that the counterparties will default on their obligation, and liquidation risk, i.e., the risk that the pledged collateral will not be sold/liquidated on the market quickly enough and without incurring a significant discount. ${ }^{127}$ This opacity made it difficult for market participants to effectively price the risk underlying transactions and to accurately evaluate counterparty risk and collateral quality. Due to the overall lack of comprehensive data and information on the structure and size of the repo market, it was difficult for regulatory agencies and market participants to map or assess the risk underlying the repo market. This made it challenging for policy makers to develop the most effective policy options and to adopt the required measures to monitor, control, and mitigate such risk.

\footnotetext{
126 The Fed and the SEC are the two main regulatory agencies involved in the collection of data on the repo market. The data collected by these agencies, however, are confidential and - most importantly missing critical elements related to firms' repo activities. The Fed, for instance, collects data on primary dealers via the FR 2004 Reporting Form and through form FR Y-9C for bank holding companies, while the Consolidated Reports of Condition and Income for depository collects quarterly data on the value of their repos and reverse repos, as well as on the valuation of collateral in these transactions. Similarly, the SEC collects data from money market funds and non-primary broker-dealers via a variety of reporting forms, as the X-17A-5 for dealers, the N-MFP, the N-CSR, and the N-SAR for money market mutual funds. See Viktoria Baklanova, Repo and Securities Lending: Improving Transparency with Better Data, Office of Financial Research Brief Series 15-03, 3-6 (Apr. 23, 2015) (discussing mechanisms to improve transparency in the securities funding market).

${ }^{127}$ Both the lack of comprehensive data on the status of the market and at the same time the complexity of the few information available made market participants more prone to the herd behaviours and intellectual biases and thus more exposed to panic shocks and reactions, see GEOFFrEY P. MiLLER, TrusT, RISK, AND MORAL HAZARD IN FINANCIAL MARKETS (2011) (investigating how trust operates in financial markets).
} 
B. THE TRI-PARTY REPO MARKET: INTRADAY CREDIT EXPOSURE, MORAL HAZARD, AND CONFLICT OF INTEREST

Although its response to the Crisis was better than that of the bilateral OTC market, ${ }^{128}$ the tri-party repo market still contains three main flaws that expose it to potential instability and make overall efficient market functioning problematic.

\section{Intraday credit exposure}

The first failure in the tri-party repo market connects to the mechanics of the business performed by the clearing banks. As previously described, ${ }^{129}$ tri-party clearing banks are agents in the transaction; they are not part of the deal and their allotted function is restricted to the collateral management business. However, as the Crisis unfolded, clearing banks altered their original business model and offered their repo clearing clients intra-day credit extension to facilitate the rollover of deals. This changed their role: they stopped being agents and instead became principals and creditors for their clients. Simply put, in the early morning of every day, clearing banks unwound all repos - even non-maturing repos - and returned cash to the repo lenders' accounts and securities to the repo borrowers'. However, before new trades were executed in the late afternoon, at which time cash was moved from the lenders' to the borrowers' accounts and securities transferred from the borrowers' to the lenders' accounts, the clearing banks financed the borrowers' securities by extending credit on an unsecured basis. ${ }^{130}$ However, these mechanisms were inherently fragile because the clearing banks acted on the assumption that every repo would have been rolled over on a daily basis and that repo lenders were committed to extending secured loans via repo to their counterparties. ${ }^{131}$ By unwinding non-maturing repos, the clearing banks were exposed to significant intra-day credit exposure - the clearing banks, in fact, financed the repo borrowers' securities that were pledged as collateral. It became clear when examining the clearing bank business model, which extended intra-day credit to repo borrowers, that it was rife with potential vulnerabilities that would have destabilized the entire tri-party repo market. Clearing banks built their business on three assumptions that later proved to be false: that clearing banks are simple agents; that tri-party repo runs are unlikely and secured funding is durable and stable; and that collateral is an effective risk mitigant. ${ }^{132}$ These factors exposed

\footnotetext{
128 See Adam Copeland et al., Key Mechanics of the U.S. Tri-Party Repo Market, 18 Fed. Res. BANK OF N.Y. YORK ECON. POL. REv. 17 (2012), available at http://www.ny.frb.org/research/epr/12v18n3/1210cope.pdf.

129 See Section II.A.1.

130 See Coplan et al., supra note 128, describing the mechanisms and weaknesses of the tri-party repo market. Repo trades were generally unwound by the clearing bank at 8:30 am and new trades were completed at 6:30 pm, exposing the clearing bank to a 10-hour credit exposure to repo borrowers. 131 Id. at 21-24.

132 See Susan McLaughlin, The Federal Reserve in the 21st Century: Tri-party Repo Market Reform, presentation at

"The Federal Reserve in the 21 st Century" Symposium, available at
} 
the tri-party clearing banks and the tri-party repo market to the risk of collapse, triggering serious concerns on the part of regulators. 133

\section{Moral hazard and conflict of interest in tri-party clearing banks}

Third-party clearing banks are financial institutions. On the one hand, they provide financial markets with an essential infrastructural service; on the other, they are active market participants operating within the markets, competing for market shares, and actively investing or speculating in different projects. Clearing banks operate as utilities in the repo market, offering collateral clearing within a big conglomerate of financial activities. Such commingling of private interests and public functions run by the same entities might create distortive incentives in clearing bank financial institutions. This might bring about two undesired outcomes: increased moral hazard for the clearing banks and a potential conflict of interest in performing their clearing functions. A clearing bank might take excessive risks in its private activities on the assumption that its role as a clearing bank in the repo market and its performance of a utility function would grant it a "too important to fail" status that might guarantee public support - either in the form of financial assistance or a bailout - in a situation of financial distress. Similarly, as market participants operating different lines of business and competing for market shares with the very same financial institutions that they assist in repo clearing, these banks might be incentivized to offer clearing services to their competitors at higher prices or impose higher costs in order to reduce their competitiveness and exploit their utility function.

In conclusion, the fact that a market utility function is performed by private financial institutions that offer services ancillary to their main investment business exposes clearing banks to a conflict of interest that might require placing the repo clearing business in the hands of standalone clearing utilities.

http://www.newyorkfed.org/education/pdf/2013/mcLaughlin.pdf and https://www.youtube.com/watch?v=Cv8grHZCn7I.

133 The tri-party repo market and its business model were the target of the only regulatory action in the repo market. The NY Fed called for the setup of a joint public and industry task force with the purpose of fixing the flows in the tri-party market. In February 2012, the Industry Task Force published seven main recommendations to strengthen the tri-party repo market; see Task Force on Tri-Party Repo Infrastructure - Payments Risk Committee, Final Report, February 15, 2012, available at http://www.newyorkfed.org/tripartyrepo/pdf/report_120215.pdf. All of the documents, materials, and results of the Task Force are available at http://www.newyorkfed.org/tripartyrepo/index.html. The seven recommendations aim at reducing credit demand by not unwinding non-maturing trades; reducing the window to unwind and roll over repos; increasing the transparency of the process and its efficiency by automating the trading mechanism; and reducing the maximum amount of intraday credit a clearing bank can provide. Since the Final Report was published, the repo industry has been actively involved in a reform process of tri-party mechanisms. The tri-party clearing banks - JP Morgan and BNYM - closely worked with their clients to change their repo clearance business model and to reduce their intraday credit exposure, and as of June 2015, 'the share of tri[-]party repo volume that is financed with intraday credit from a clearing bank has dropped markedly, from 100 percent as recently as 2012, to a level averaging 3 to 5 percent today;' press release available at http://www.newyorkfed.org/newsevents/statements/2015/0624_2015.html. 


\section{SYSTEMIC RISK: INTERCONNECTEDNESS AND PRONENESS TO RUNS}

Another intrinsic problem of the repo market is its main structure. The repo market is dominated by a few participants who exploit rent-seeking positions, which imposes high entry costs on potential new players. The current actors in the repo market are connected in a dense net of transactions, relying heavily on their counterparties to support their financing. As the Crisis revealed, reputation is one of the pillars on which the market is founded, and such a strong reliance on confidence makes the repo market more prone to the risk of run. The Crisis - and the Bear Stearns and Lehman Brothers cases - revealed how crucial reputation and confidence are to the stability of the repo market. A reputational decline or a more drastic loss of confidence in one of the market participants or in an asset class has the potential to destabilize the whole market. This situation is further exacerbated by the maturity and liquidity structure of a repo. Repos are shadow banking instruments: they create short-term, liquid claims that are invested in long-term, illiquid assets. Much like bank deposits, the repo market is intrinsically unstable due to its maturity and liquidity mismatch. Unlike the bank deposit system, the repo market lacks the public guarantees and mechanisms that have been introduced in the banking system as stability buffers - i.e., deposit insurance and capital requirements.

As described by Gary Gorton and Andrew Metrick in their seminal works on the shadow banking system, a repo run occurs when repo lenders withdraw their money from the market. This can happen in two distinct ways, both of which were experienced in the run leading up to the Crisis. First, repo lenders can simply decide not to roll over their repo financing when the repo matures; second, a repo lender can ask for an increase in the haircut, thus asking the repo borrower to post additional collateral as a guarantee of its funding position. ${ }^{134}$

\section{WHO IS RESPONSIBLE FOR THE REPO MARKET? REGULATORY AND SUPERVISORY MISALIGNMENTS BETWEEN THE FED AND THE SEC}

The repo market is a structural segment of the shadow banking system, which expanded through regulatory arbitrage between banking and securities regulation. For this reason, the repo market developed in an opaque and unsupervised environment. Repos are securities market instruments, but at the same time they provide banking-like functions in the form of both deposit-like instruments and credit. Some repo market participants - MMMFs, broker-dealers, etc. - are financial entities that traditionally fall under the supervisory umbrella of the SEC;

\footnotetext{
134 The authors describe in detail how the drop in value of the securitized products pledged as collateral in repo transactions triggered extensive margin calls by repo lenders. Facing extensive margin calls, many repo borrowers decided to default on the repo, leaving repo lenders with huge portfolios of depreciated assets. Repo lenders tried to liquidate these assets on the market, triggering a fire sale that exacerbated the downturn spiral of asset prices.
} 
others - i.e., depository banks and bank holding companies - are entities that fall under the Fed's radar. The lack of a comprehensive and coordinated supervisory framework for the repo market resulted in an absence of relevant data collection and a lack of preemptive stability buffers or mechanisms in the system. The SEC has a three-part mission: to protect investors; to maintain fair, orderly, and efficient markets; and to facilitate capital formation. ${ }^{135}$ Even after the implementation of the so-called "consolidated supervised entities" program, which allowed broker-dealers and their affiliates to voluntarily opt in to the SEC financial stability supervisory framework, ${ }^{136}$ the SEC proved that it lacked macroprudential regulatory and supervisory expertise. Similarly, the Fed, while collecting individual data on repo and reverse repo transactions operated by primary dealers and operating in the repo market for monetary policy purposes, completely ignored the repo market, on the assumption that market participants and the market structure would have aligned their incentives and mitigated market risk.

\section{IS THERE A CASE FOR REGULATING THE REPO MARKET? THE FINANCIAL MARKET INFRASTRUCTURE PATH}

Thus far, this paper has examined the structure of repo contracts and the repo market, assessed the active role that repos played in the propagation of the Crisis, and identified the market failures that make the repo market vulnerable to systemic risk and expose it to market inefficiency. These failures call for a reform of the repo market and push back against the regulatory void that we are currently facing. Regulators should therefore counter-cyclically intervene in order to regulate the repo market.

In the aftermath of the Crisis, the academic debate on this topic has been quite limited. However, a handful of scholars have examined distinctive aspects of the repo market and provided various alternatives as to how best to intervene. Legal scholars, focusing on the special treatment reserved for repos in the Bankruptcy Code, argue in favor of narrowing the repo bankruptcy safe harbors. ${ }^{137}$ Darrell Duffie, a finance scholar from Stanford University who investigates the "plumbing of the financial system," envisions standalone regulated

\footnotetext{
135 See SEC, The Investor's Advocate: How the SEC Protects Investors, Maintains Market Integrity, and Facilitates Capital Formation, available at http://www.sec.gov/about/whatwedo.shtml; and SEC, http://investor.gov/introduction-markets/role-sec.

136 See SEC 17 CFR Parts 200 and 240 [Release No. 34-49830; File No. S7-21-03] RIN 3235-AI96 Alternative Net Capital Requirements for Broker-Dealers That Are Part of Consolidated Supervised Entities. The "consolidated supervised entities" rule has been identified as one of the regulatory failures that contributed to the financial crisis. See John Carney, The SEC Rule That Broke Wall Street, March 21, 2012, available at http://www.cnbc.com/id/46808453; Stephen Labaton, S.E.C. Concedes Oversight Flaws Fueled Collapse, September 26, 2008, available at http://www.nytimes.com/2008/09/27/business/27sec.html.

${ }_{137}$ Morrison et al., supra note 120; Duffie \& Skeel, supra note 120.
} 
clearing utilities for the tri-party repo market. ${ }^{138}$ NYU Stern School of Business scholars Viral V. Acharya and T. Sabri Öncü focus on systemically important assets and liabilities, calling for a repo resolution authority for the orderly liquidation of illiquid underlying collateral as an ex-post mechanism to mitigate moral hazard and induce market discipline. ${ }^{139}$ Yale University scholars Gary Gorton and Andrew Metrick look at the repo market in the broader context of reforming the shadow banking system and imagine the creation of a binary repo market with a stricter regulation of eligible collateral, minimum haircuts, and licensed entities. ${ }^{140}$ Finally, Morgan Ricks, a former Treasury official now at the Vanderbilt School of Law, focuses on repos as money market instruments, arguing in favour of establishing money creation as a sovereign responsibility by means of a private-public partnership system. ${ }^{141}$

This paper acknowledges the current scholarly debate and policy options, and offers an original alternative policy option to restore the repo market. This option is built on the central role of financial market infrastructure (FMI) and is achievable in the form of a two-step process. The first step aims at fostering transparency in the repo market - an issue left almost untouched by the current scholarly debate. The second step focuses on strengthening the repo market's structural mechanisms and stability, and at promoting its efficiency. This policy proposal has its foundations in the post-Crisis reform of the OTC derivatives market and in two of the pillars underlying the structural reorganization of that market: transparency and central clearing. Title VIII of the Dodd-Frank Act introduced these reforms in the OTC derivatives market, and this paper argues in favour of extending the same set of rules to the repo market.

\footnotetext{
138 Duffie, supra note 10; Darrell Duffie, How Big Banks Fail - And What to Do about It (2011), investigating the structural fragilities of dealers' banks and their unstable short-term funding structure. 139 Viral V. Acharya \& T. Sabri Öncü, A Proposal for the Resolution of Systemically Important Assets and Liabilities: The Case of the Repo Market, 9 INT. J. OF CENT. BANkIng 291 (2013).

140 Gorton, SLAPped by The Invisible Hand, supra note 7; GARY B. GorTOn, Misunderstanding Financial Crises - Why We Don’t See Them Coming (2012); Gorton \& Metrick, Regulating the Shadow Banking System, supra note 10; Gorton \& Metrick, Securitized Banking and the Run on Repo, supra note 7. The authors suggest that repos, as demand deposits, are information-sensitive instruments, and are thus vulnerable to panics when adverse information surfaces about the quality of the underlying collateral or the stability of the counterparties. Their proposal aims at creating information-insensitive repos replicating the effects of federal deposit insurance on the stability of bank deposits. The authors' option would create two different types of repos: 'the first type, offered to commercial banks and [narrow funding banks], would capture the monetary function of repos,' while the eligible collateral to be pledged in these transaction would be 'restricted to U.S. Treasury securities, liabilities of [narrow funding banks],' and all collateral used in repos would be required to be subject to minimal collateral. The second type repos not used as deposits or monetary instruments - 'could be offered by any institutions with a license,' and would be subject to stricter minimum haircut requirements and positions limits.

141 Morgan Ricks, Money and (Shadow) Banking: A Thought Experiment, 31 Rev. OF BANK. \& FIN. L. 731 (2011-2012); Morgan Ricks, Regulating Money Creation After The Crisis, 1 HARv. BusinEss L. Rev. 75 (2011); Morgan Ricks, A Regulatory Design for Monetary Stability, supra note 10; Morgan Ricks, Reforming the ShortTerm Funding Market, Harvard University John M. Olin Center for Law, Economics and Business Discussion Paper No. 713 (2012), available at http://ssrn.com/abstract=2062334.
} 


\section{A. STEP ONE: MAKING THE MARKET TRANSPARENT - THE ROLE OF TRADE REPOSITORIES}

As previously described, the opacity of (and in) the repo market is one of most serious weaknesses unveiled by the Crisis. Repos, much like derivatives, expanded in the OTC world, a marketplace dominated by private information in which public information and transparency cowered in the background. Repo market opacity is not only a threat, at a macroprudential level, to financial stability posing a risk to authorities trying to effectively oversee the market - but also represents a market inefficiency at a transactional level vis-à-vis market participants, preventing them from effectively assessing and pricing the risks underlying repo transactions - namely, counterparty risk and liquidation risk.

The transparency option is a necessary first step toward creating a more resilient repo market. Imposing mandatory reporting of repo transactions to centralized entities would provide regulators and markets with aggregated data on a variety of market variables. Armed with this data, regulators would be able to more effectively address macroprudential risk. Similarly, incentivizing the trading of repos in trading venues would strengthen transactional transparency, thus increasing the efficiency of the market by improving risk pricing mechanisms. Internationally, regulators have begun to explore the option of fostering transparency in the repo market. Those efforts - in particular the two paths followed by the FSB and the EU in addressing opacity in the repo market - will be addressed in the next two sections.

1. The FSB policy framework. for addressing shadow banking risk in securities lending and repos As already mentioned, the post-crisis regulatory debate neglected to consider reforming the repo market. It was only at the end of 2011, when the FSB released a broad and very ambitious plan to strengthen the oversight and regulation of the shadow banking system, that this issue emerged. ${ }^{142}$ One of the plan's five pillars was the regulation of securities lending and repos. ${ }^{143}$ The FSB considered the secured funding market to have facilitated the growth of shadow banking activities in the pre-crisis world, and to have accelerated the Crisis itself. The FSB recognized that repos had enhanced the financial system's interconnectedness through its chains of transactions by facilitating maturity and liquidity transformation and by increasing leverage within financial institutions. ${ }^{144}$ Thus, the 2011 FSB proposal addressed the systemic risk in the repo market with two primary interventions: macroprudential measures related to the transparency of

\footnotetext{
142 See FSB, Shadow Banking: Strengthening Oversight and Regulation - Recommendations of the Financial Stability Board (October 27, 2011) available at

http://www.financialstabilityboard.org/2011/10/r_111027a/ (hereinafter FSB, October 2011 Report). 143 See FSB, October 2011 Report, Recommendation 8 "Regulation of secured funding markets, in particular repos and securities lending should be assessed carefully and further enhanced from the prudential perspective as necessary", at 22-24. 144 Id.
} 
the market and microprudential measures vis-à-vis margin requirements and haircuts to reduce procyclicality.

In August 2013 - following the release of an Interim Report in 2012, which assessed some of the financial stability issues connected to the repo market, ${ }^{145}$ and after a consultation phase ${ }^{146}$ - the FSB published its Policy Framework for Addressing Shadow Banking Risks in Securities Lending and Repos. ${ }^{147}$ The FSB's Policy Framework identified three main policy interventions: steps related to improving transparency; microprudential regulation of securities financing; and steps related to macroprudential structural aspects of the securities financing markets.

With regard to transparency, the FSB stressed the need for regulators to collect timely granular and aggregated data on repo transactions occurring at both international and national financial institutions. ${ }^{148}$ The disclosure of such information and the resulting increase in transparency would provide authorities with more effective monitoring mechanisms through which to oversee and detect risk in the market. ${ }^{149}$ To promote this outcome, the FSB recommended improving disclosure by global financial institutions about their activities and exposures in the repo and securities lending markets, ${ }^{150}$ as well as enhancing fund managers' corporate disclosure and reporting about their activities and exposure in these markets to end-investors. ${ }^{151}$ Collecting quantitative data on the size of repo

\footnotetext{
145 See FSB, Securities Lending and Repos: Market Overview and Financial Stability Issues - Interim Report of the FSB Workstream on Securities Lending and Repos (April 27, 2012) available at http:/ /www.financialstabilityboard.org/2012/04/ fsb-report-on-securities-lending-and-repos-marketoverview-and-financial-stability-issues/ [hereinafter FSB, Interim Report].

146 See FSB, Consultative Document - Strengthening Oversight and Regulation of Shadow Banking - A Policy Framework for Addressing Shadow Banking Risks in Securities Lending and Repos November 18, 2012) available at http://www.financialstabilityboard.org/2012/11/r_121118b/; the consultation phase was quite active and the FSB received 18 responses that are available on the FSB website, FSB, Public responses to April 2012 consultative document Interim Report on Securities Lending and Repos (May 6, 2012) available at

http://www.financialstabilityboard.org/2012/05/c_120807/.

147 See FSB, August 2013 Report, supra note 11.

148 See $i d$. Recommendations 1 and 2, at 6-8. In implementing these recommendations, the FSB has recently published the standards and process for global data collection and aggregation on securities financing transactions (repos and securities lending). This document identifies and defines the repos' 'data elements' to be collected and reported to the FSB (i,e. value date, maturity date, collateral type, collateral quality, haircut, principal amount, counterparty type, repo market segment, repo rate, currency, etc.); and sets out the two tier architecture for the repo market data collection and aggregation. Tier one national/regional level: collection of data from the market. Tier two - aggregation of national/regional data by the FSB to provide global trends of securities financing markets. See FSB, Transforming Shadow Banking into Resilient Market-based Finance - Standards and processes for global securities financing data collection and aggregation (November 18, 2015), available at http://www.financialstabilityboard.org/2015/11/standards-and-processes-for-global-securitiesfinancing-data-collection-and-aggregation-3/.

${ }_{149}$ Underlying the global and cross-border dynamics of the securities financing markets, the FSB takes responsibility for the monthly aggregation and public disclosure of future national and regional data for both repos and securities lending, with the aim of providing information on the global trends in these markets; see $i d$. Recommendation 3 at $9-10$.

150 See id., Recommendation 4, at 10-11.

151 See id., Recommendation 5, at 11-12.
} 
exposure and qualitative data on the underlying collateral of repo transactions would enable authorities to more effectively supervise the repo market and when necessary - intervene to mitigate the systemic risk. Finally, the FSB required national and regional authorities to implement the most appropriate measures to collect the required data, recommending a certain level of standardization and harmonization in designing the disclosure models.

The microprudential regulation of securities financing focuses on the role and treatment of collateral in repo transactions. The FSB position was built around the issues related to the re-hypothecation of collateral, as well as the valuation and treatment of collateral. The FSB pushed for minimum standards for evaluating and managing collateral, and heightened disclosure by intermediaries in relation to the re-hypothecation of assets. ${ }^{152}$ Finally, the FSB took positions on potential macroprudential structural aspects of the repo market. ${ }^{153}$ The international policy forum leaves national and regional authorities with the task of evaluating the costs and benefits of introducing or supporting CCPs in the interdealer repo market as a measure through which to mitigate systemic risk. ${ }^{154}$ Similarly, national and regional authorities are the final arbiters of whether to amend the special legal treatment of repos under bankruptcy law. ${ }^{155}$

The FSB proposal touched on a wide range of possible policy options. The most advanced and developed recommendations, however, focused on improving repo market transparency. ${ }^{156}$ Stressing the importance of standardizing information collection, the FSB advanced three mechanisms - regulatory reports, compulsory market surveys, and trade repositories - that authorities could implement in order to collect data to support their monitoring activities at a domestic level. Each of these options presents advantages and disadvantages.

Regulatory reports may be a feasible and cheap solution to overcome repo market opacity in those jurisdictions where the macroprudential supervision of the financial market is empowered in a single regulatory authority that is responsible for the oversight of financial firms. However, such a solution may be problematic where financial firms are supervised by multiple public or private authorities. Furthermore, regulatory reporting may have difficulty capturing high-frequency reporting, and this reporting may occur at a considerable time lag. ${ }^{157}$

Conversely, mandatory market surveys run by industry associations, central banks, or financial authorities that periodically collect significant information on market development may be an effective approach in jurisdictions with multiple regulatory authorities and different reporting regimes. However, such an approach might lack the enforcement tools to ensure that all significant participants

\footnotetext{
152 See id., Recommendations 6-9, at 12-17.

153 See id., Recommendation 10, at 17-18.

154 The FSB, while referring to the 'inter-dealer repo segment', identifies a repo market that 'comprises primarily government bond repo transactions amongst banks and broker-dealers.' See FSB, Interim report, supra note 145.

155 See FSB, August 2013 Report, supra note 11, Recommendation 11, at 18-19.

156 See id., Annex 4, at 40 ss.

157 Id. at 42.
} 
contribute to the data collection, mainly in those scenarios where market surveys are run by industry associations. Furthermore, as for regulatory reports, market surveys may only register data with a considerable time lag. ${ }^{158}$

Finally, a third approach - as adopted in the post-Crisis regulation of OTC derivatives - requires a trade repository (TR) to collect, process, and publish data on all transaction activity across all market participants and clearing agents in the repo market. In this scenario, a TR acts as a financial market infrastructure, providing utility services to public authorities and to the market. TRs may overcome the problems inherent in regulatory reports and market surveys. If market participants are mandated by regulators to report all data to a TR, as adopted for the OTC derivatives market, that TR may provide timely, frequent, and comprehensive data on all market participants, regardless of regulators. ${ }^{159}$ This approach, however, may require an upfront investment in order to establish and run a TR - regulatory and economic costs that have already been incurred in order to set up TRs for OTC derivatives.

All three approaches are feasible mechanisms through which to increase transparency, require and promote standardization in data disclosure, and support effective supervision of risk in the repo market. The first two solutions present structural commonalities in the way they collect historical data and provide periodic information on the size and characteristics of the repo market. Both options are relatively cheap in terms of implementation costs. However, they are not structured in a way that captures high-frequency data reporting and they may not function as well in an international framework. In contrast, the TR solution was used in the post-Crisis reform of the OTC derivatives market, and, despite presenting potential implementation costs - TRs are private firms that perform a market utility function - would provide public financial authorities with standardized, timely, and accurate granular and aggregated data on the repo market. In fact, TRs would probably be particularly useful in jurisdictions like the US, where repo market participants are a very diverse group of actors - regulated and supervised by different entities - financing a diverse mix of assets in the repo market. ${ }^{160}$

\section{The EU Proposal for regulating the reporting and transparency of securities financing transactions}

The EU is the first jurisdiction to have reached an agreement on a legislative proposal aimed at introducing mandatory repo trade reporting to centralized TRs. ${ }^{161}$ That proposal - part of the action plan on shadow banking presented by

\footnotetext{
$158 \mathrm{Id}$.

${ }^{159} \mathrm{Id}$.

${ }^{160} I d$. at 42.

161 See EC, Proposal for a Regulation of the European Parliament and of the Council on reporting and transparency of securities financing transactions (Jan. 29, 2014) COM(2014) 40 final 2014/0017 (COD),
} 
the European Commission (EC) in September 2013162 - emphasized the importance of collecting data 'to observe the risks associated with interconnectedness, excessive leverage and procyclical behaviours...'163 The proposed regulation attempted to increase transparency in the securities financing transactions (SFTs) market in three ways. ${ }^{164}$ First, it fostered market and macroprudential transparency (transparency towards regulators) by requiring mandatory reporting of all SFTs (except those concluded with central banks) to central databases, namely TRs. ${ }^{165}$ Second, it increased investor-facing transparency by requiring investment funds to inform their investors about their use of STFs and other financing structures. ${ }^{166}$ Third, it boosted contractual and microprudential transparency by limiting the right of the collateral receiver to rehypothecate the securities received only in situations when the following two conditions were satisfied: (i) the provider of the collateral has granted express consent, and (ii) the provider has been duly informed - in writing - of the risks involved in granting consent, and, more specifically, of the potential risks should the collateral receiver default. ${ }^{167}$

\section{What to learn from the FSB and EU initiatives: A blueprint for increasing transparency in the US repo market}

As already sketched out in Section III.A, the opacity of the repo market was one of the reasons why authorities were caught unawares and unprepared when the market froze. Authorities knew that financial markets relied heavily on the repo market as a source of liquidity, but they did not know how deep and critical that dependency was. The status quo of data sources - as described in Section III.A - is alarming. On the one hand, the NY Fed's primary dealers survey shows data on

available at http://eur-lex.europa.eu/legal-content/EN/TXT/?uri=CELEX:52014PC0040 [hereinafter EC, Proposal].

162 See EC, Communication from the Commission to the Council and the European Parliament, Shadow Banking - Addressing New Sources of Risk in the Financial Sector (Sep. 4., 2013) COM(2013) 614 final, available at http://eur-lex.europa.eu/legal-content/EN/TXT/?uri=CELEX:52013DC0614 (hereinafter EC, Communication 2013).

163 See id. at 10.

164 See EC, Proposal, supra note 161.

165 See id. art. 4. Art. 4.7 generally identifies (secondary-level regulation is deemed to be implemented) the details of SFTs that should be disclosed: the parties of an SFS; the principal amount, currency, and type; the quality and value of the collateral; the method used to provide the collateral; where it is available for rehypothecation; the purchase rate; the counterparty; the haircut and maturity date, etc. It is noteworthy to mention that art. 2.2 of the proposal expressly exempts the BIS from mandatory reporting, as well as the 'members of the European System of Central Bank (ESCB) and other Member States' bodies performing similar functions and other union public bodies charged with or intervening in the management of the public debt.' Furthermore the ECB, in its published proposal option, strongly recommended including in the proposed regulation a transaction-based 'exemption with regard to transactions to which an ESCB central bank is a counterparty.' See ECB, Opinion of the European Central Bank on a proposal for a Regulation of the European Parliament and of the Council on reporting and transparency of securities financing transactions (June 24, 2014) (CON/2014/49) (2014/C 336/04).

166 See EC, Proposal, supra note 161, art. 13.

${ }^{167} I d$. art. 15. 
repo transactions for primary dealers. ${ }^{168}$ On the other, SIFMA - the financial industry association - and the Tri-party Repo Infrastructure Reform Task Force collect and publish monthly data on all tri-party repo market activity in the US. ${ }^{169}$ The collected data reflect only two segments of the whole repo market: tri-party markets and primary dealers. Data collection completely relied on monthly regulatory reports. This situation was and is suboptimal for market transparency; however, the range of possible reforms is wide and an effective solution has been developed and tested for a different segment of the financial market, the OTC derivatives market.

As of today, no initiatives are being discussed with the goal of setting up a uniform and harmonized transparency regime for the repo market. To strengthen transparency in the repo market, lawmakers may follow the same approach used to illuminate the dark OTC derivatives market: mandating that all repo transaction activity across all market participants be reported to TRs.

TRs, operating as market utilities, will collect, store, process, and disseminate all available data on the repo market. ${ }^{170}$ By accessing the data collected by TRs, regulatory entities will be able to more effectively monitor the status of the repo market in order to address the risks and vulnerabilities that might arise, and to conduct well-informed supervisory and regulatory activities. In addition, TRs will be beneficial for market participants and the public, who will have access to more detailed information on market trends and data services from TRs. The implementation costs for this reform would be limited. Title VII of the DoddFrank Act and the implementing regulation adopted by the CFTC and the SEC have already regulated TRs, including their governance, structure, and activities. TRs are already operating in the OTC derivatives market; extending their business to repo market data collection might be an efficient and profitable solution to offset the establishment and compliance costs related to setting up OTC derivatives businesses.

\footnotetext{
168 See http://www.newyorkfed.org/markets/statrel.html; the NY Fed has recently reformed the approach used to deliver to the public the data on the tri-party repo market by introducing an interactive platform; see Jacob Adenbaum et al., The Tri-Party Repo Market Like You Have Never Seen It Before, Liberty STREET ECONOMICS, (October 19, 2015, 7:00 AM), http:/ /libertystreeteconomics.newyorkfed.org/2015/10/the-tri-party-repo-market-like-you-have-neverseen-it-before.html\#.VmcAc7iLTGg; the new interactive charts on the volume of the tri-party repo market for each asset class are available at https://www.newyorkfed.org/data-and-statistics/datavisualization/tri-party-repo/index.html\#interactive/volume. ${ }^{169}$ See http://www.newyorkfed.org/banking/tpr_infr_reform_data.html.

170 The effectiveness of data collection by TRs would be strengthened in a market scenario where a high share of transaction activities is centrally cleared. See Section V.B.2. for a more detailed analysis of the role and benefit of having CCPs in the repo market.
} 


\section{B. STEP TwO: THE ROLE OF FINANCIAL MARKET INFRASTRUCTURE - TRADING VENUES AND CENTRAL CLEARING COUNTERPARTIES}

Once opacity in the repo market is reduced by mandating disclosure mechanisms with TRs, the second step of the proposed repo market reform tries to comprehensively address the remaining failures in the repo market. While strengthening transparency is a less intrusive reform, the second step - the establishment of FMI (namely CCPs and trading venues) - is more invasive, as it would seek to resolve problems with the repo market - systemic risk, counterparty credit risk, and market inefficiencies - beginning at the foundation of the market structure. In a nutshell: similar to the development of a comprehensive transparency regime, the establishment of FMI envisions a structural reform of the plumbing of the repo market, with trading venues and CCPs acting as public utilities in promoting market efficiency and fostering financial stability.

FMIs are multilateral systems at the heart of the financial system that reduce, mitigate, or allocate the inherent risks and costs arising from transactions between market participants. ${ }^{171}$ Some facilitate the matching of demand and offer for the purchase of securities; others ease the transfer of cash and securities to settle a transaction or record; and still others intermediate and clear exposures between counterparties, guaranteeing the performance of financial obligations. ${ }^{172}$

The FMI step is built on two pillars, each of which is an actual market utility. The first pillar is the trading venue. Trading venues - structured either as exchanges, electronic platforms, or alternative trading systems - sustain transparency and price discovery in the market, push for higher standardization of contractual terms (which in turn lower transaction costs), and further market efficiency. CCPs form the second pillar and play a crucial and systemic role in the repo market resulting from the proposed reforms. They would not only intervene in the mitigation of systemic and counterparty credit risk, they would also act as systemic stability buffers and would break the current conflict of interests and oligopolistic scenario in the tri-party repo market.

\section{Trading venues}

US repos are largely traded in OTC markets, which are private, informal, discretionary, bilateral, and opaque marketplaces. ${ }^{173}$ Dealers or intermediaries are at the centre of OTC markets, either trading directly and bilaterally with their customers and clients or trading with their peers in the inter-dealer segment. Dealers choose the participants with whom they want to trade; similarly, they

\footnotetext{
171 Amandeep Rehlon, Central Counterparties: what are they, why do they mater and how does the Bank supervise them?, 53 QUARTERLY BuLL. 147 (2013), available at

http://www.bankofengland.co.uk/publications/Documents/quarterlybulletin/2013/qb1302.pdf.

172 Id. at 149; See also BIS, Committee on Payment and Settlement Systems, Technical Committee of the International Organization of Securities Commissions, Principles for Financial Market Infrastructures (April 2012) available at http://www.bis.org/cpmi/publ/d101a.pdf, at 7.

173 See Guido Ferrarini \& Paolo Saguato, Regulating Financial Infrastructure, in OXFORD HANDBOOK OF FinAnCial Regulation (Niamh Moloney et al. eds., 2015).
} 
unilaterally quote the prices at which they will sell or buy, which can vary from customer to customer. ${ }^{174}$ OTC markets are not equally open to all participants: dealers have discretion regarding trades and the participants with whom they trade. ${ }^{175}$ An informal, discretionary market not only affects the capacity of dealers to choose their counterparties and set the prices they want, but also allows - as happened in the midst of the Crisis - dealers in the OTC market to walk away and withdraw from the market at any time. ${ }^{176}$ The sudden disappearance of dealers as trading counterparties and "market makers" directly hits the supply of liquidity, thus reducing the ability for market participants to find trading opportunities. Furthermore, in OTC markets, the lack of published pre- and post-trade information reduces the ability of market participants to effectively assess the risk underlying the transaction and the counterparty credit risk of the dealer and thus price it accordingly. In one example, a market participant may need to conclude a trade - e.g., a securities dealer looking to "repo in" securities to cover an open exposure. In this situation, without publicly available information, the securities dealer might be unable to effectively negotiate the economic terms of the trade and would have to accept the price imposed by the intermediary. Some may argue that these are simple market dynamics that occur when parties contract freely in an open market and walk away from the negotiation when the contractual terms are economically unappealing. However, the result achieved is suboptimal in a financial market scenario where there is a structural dependence on repo transactions to finance short-term liquidity and repo dealers are in the dominant position. Similarly, one can imagine a situation in which the dealer is one of the largest market actors, in which case there would be pressure on the intermediaries to lower the price of the trade in order to keep open new market opportunities.

A final remark on the structural weakness of the OTC repo markets relates to potential structural instability. Dealers can, in fact, withdraw from market making, thus suddenly depriving participants of a private marketplace in which they can finance their activities or invest their liquidity. This is precisely what happened during the Crisis: the main repo dealers pulled out of the market when they sensed the systemic instability and unreliability of the financial system. This contributed heavily to the drying up of the repo market's liquidity.

How can we move forward from the current situation? Repo transactions are highly standardized contracts, and the industry private-standard-setting organization, SIFMA, has worked diligently to increase the standardization and harmonization of the American repo market agreement, MRA, with its globalEuropean equivalent, GMRA. ${ }^{177}$ By standardizing contractual terms and harmonizing the legal framework for cross-border transactions, SIFMA aims to

\footnotetext{
174 See generally Randall Dodd, Market: Exchange or Over-the-Counter (March 28, 2012), http://www.imf.org/external/pubs/ft/fandd/basics/markets.htm.

${ }^{175} \mathrm{Id}$.

${ }^{176} I d$.

177 See http://www.sifma.org/issues/capital-markets/rates/repo-and-secured-lending/overview/.
} 
reduce transaction costs and increase legal certainty in repo trades in order to sustain the repo market's liquidity. The introduction of trading venues in the repo market would be feasible only if the instruments to be traded are liquid and have marketability. No venues would, in fact, accept illiquid instruments for trading.

To foster liquidity in the repo market and support pre- and post-trade market transparency, regulators should consider supporting the establishment of repo trading venues. ${ }^{178}$ Although the concept of the trading venue has become fluid due to the active role that technological innovation is now playing in the financial system, a market operated by a trading venue is a public market: formal, nondiscretionary, transparent, and multilateral. ${ }^{179} \mathrm{~A}$ trading venue - be it an exchange, a multilateral trading facility, or an alternative trading system - is a self-organized entity that, by pre-setting access requirements, reduces the discretion of the venue's operator in accepting the trades. Furthermore, the execution of the trades occurs anonymously through the matching of multiple parties' orders. ${ }^{180}$ Lenders can offer their cash and borrowers can sell their collateral anonymously, "with the repo going to the highest bidder in the form of the highest rate." 181 In addition, venues publish and make available bid and offer prices to their participants, "who can respond by selling or buying at one of the quotes, or by replying with a different quote." 182 Pre- and post-trade information is therefore diffuse among all market participants who can buy and sell at the same price as other traders. The presence of trading venues would also benefit the structural elements of the repo transaction. Beyond organizing trading by providing infrastructure, defining rules, and monitoring trading participants' compliance with regulations, venues are generally closely linked to clearing facilities, where post-trading activities - namely clearing and settlement - are performed. Hence, venues would smooth over the whole trading and post-trading process.

Why is having trading venues in the repo market a desirable solution? First, trading venues would cut, or even eliminate, the high reputation entry and stay costs in the repo market. Trading venues operate under a pre-set regime and market participants are bound by the venues' rules. Trading venues do not have the discretion to refuse or walk out of a trade as a dealer in an OTC scenario can do. Once a bid and an offer are matched, the trade is concluded. Moreover, the presence of the CCP as a central counterparty for all trades makes each party indifferent to the identity and creditworthiness of its matching party; thus, the repo price is set by supply and demand. ${ }^{183}$ Second, in the OTC scenario, dealers are market makers: if they face financial distress, they withdraw from the market,

\footnotetext{
178 See Jonathan Macey \& Maureen O'Hara, From Markets to Venues: Securities Regulation in an Evolving World, 58 STAN. L. REV. 563 (2005).

179 See Ferrarini Saguato, supra note 173.

${ }^{180} \mathrm{Id}$.

181 See Jeff Penney, Out of the Shadows: Central Clearing of Repo - A Transparent Market Structure for Cash Borrowers and Lenders (April 2011) available at http://highlineadvisors.com/whitepapers/clearedrepo.html, at 18-19.

182 Dodd, supra note 174.

183 Penny, supra note 181 at 19.
} 
which results in no trading and no market. Trading venues are market infrastructures: by simply matching bids and offers, they serve a utility function without being market makers. In a situation of systemic financial distress, the overall volume of trading might shrink, but trades would not evaporate, as in the situation of a distressed dealer in the OTC market. Third, price discovery (both pre- and post-trade) would reduce transaction costs for market participants and would contribute to a more efficient assessment of counterparty and market risk. Without public direct prices or even benchmark prices, risk pricing is remitted to private models; these might be exposed to valuation bias, resulting in no easy or definite way to evaluate the security. ${ }^{184}$

\section{Central clearing counterparties}

The fulcrum of the FMI reform is the role envisioned for CCPs. ${ }^{185}$ CCPs are market utilities that perform three main operations. As their name suggests, a CCP clears a transaction by netting offsetting positions; a CCP interposes itself, becoming the legal counterparty to both sides of a transaction; and finally, a CCP stands at the centre of the market, operating as a stability and liquidity buffer. Financial and legal literature generally refer to CCPs as risk mitigation mechanisms; however, the post-crisis reforms of the OTC derivatives market, which mandated central clearing for standardized OTC derivatives, have fuelled an animated debate about the role of CCPs in the financial market. ${ }^{186}$ This section will first provide a general overview of the role that CCPs play in the financial system, with a focus on their risk management function. This will lead into an outline of the ways in which having CCPs operating in the repo market would make the market more stable, reduce the likelihood of run, and decrease the moral hazard affecting the current structure of the repo market. ${ }^{187}$

\footnotetext{
${ }^{184} I d$.

185 The academic discussion around the role of CCPs in the post-crisis financial market is wide; see generally Richard Squire, Clearinghouses as Liquidity Partitioning, 99 CoRnELL L. REV. 857 (2014); Sean J. Griffith, Substituted Compliance and Systemic Risk: How to Make a Global Market in Derivatives Regulation, 98 MinN. L. REv. 1291 (2014); Yesha Yadav, The Problematic Case of Clearinghouses in Complex Markets, 101 GEO. L. J. 387 (2013); Mark J. Roe, The Dodd-Frank. Act's Maginot Line: Clearinghouse Construction, 101 CALIF. L. REv. 1641 (2013); Mark Roe, Clearinghouse Overconfidence, 101 CAL. L. REv. 1641 (2013); Julia Lees Allen, Derivatives Clearinghouses and Systemic Risk: A Bankrupty and Dodd-Frank Analysis, 64 STAN. L. REV. 1079, 1082 (2012); Darrell Duffie \& Haoxiang Zhu, Does a Central Clearing Counterparty Reduce Counterparty Risk?, 1 Rev. Asset Pricing STUd. 74 (2011); Jeremy C. Kress, Credit Default Swaps, Clearinghouses, and Systemic Risk: Why Centralized Counterparties Must Have Access to Central Bank Liquidity, 48 HARV. J. LEGIS. 49 (2011); Hal Scott, Reduction of Systemic Risk in the United States Financial System, 33 HARV. J. L. \& PUB. POL'Y 671 (2010); Craig Pirrong, The Clearinghouse Cure, 31 REG. 44 (Winter 2008-2009); Craig Pirrong, The Economics of Clearing in Derivatives Markets: Netting, Asymmetric Information, and the Sharing of Default Risks Through a Central Counterparty (Jan. 8, 2009), available at http://ssrn.com/abstract=1340660.

186 See generally RANDAll S. Kroszner \& Robert J. SHILler, REFORMing U.S. FinANCIAL MARKETS REFLECTION BEFORE AND BEYOND DODD-FrANK (2011). This paper takes a position in the debate, but a deep discussion of that debate is outside of its scope and will be the topic of future research. 187 See Penny, supra note 181.
} 


\section{a. A clearing primer: What does a CCP do?}

Imagine a situation in which there are three parties: A, B, and C. A is a securities dealer who intends to repo in Treasury bills and use the proceeds of the sale to finance long-term investments as well as another repo transaction. B is an MMMF that is looking to invest a portion of its cash reserves and needs to remove from its balance sheet a portion of its investment in T-Bills. C is a broker-dealer who needs T-Bills to cover a short position and wants to invest part of a client's account. For the sake of simplicity, this paper examines the role of the CCP in a static moment, when the parties have agreed to the trades.

Let us first analyse a scenario in which there is no CCP and the parties have agreed on the terms of the transactions either bilaterally or via an exchange. Here, A enters into two repos: in the first one, it sells a $\$ 200$ T-Bill to B and receives $\$ 200$ back; in the second, it uses $\$ 100$ of the proceeds of the reverse repo with B to purchase a $\$ 100$ T-Bill from C. B agrees to lend A $\$ 200$ and at the same time agrees to transfer $\$ 150$ worth of T-Bills to C. Finally, C sells a T-Bill worth $\$ 100$ to $A$ and invests $\$ 150$ of a client's account to purchase a $\$ 150$ T-Bill from $B$. Here is how the bilateral transactions look:

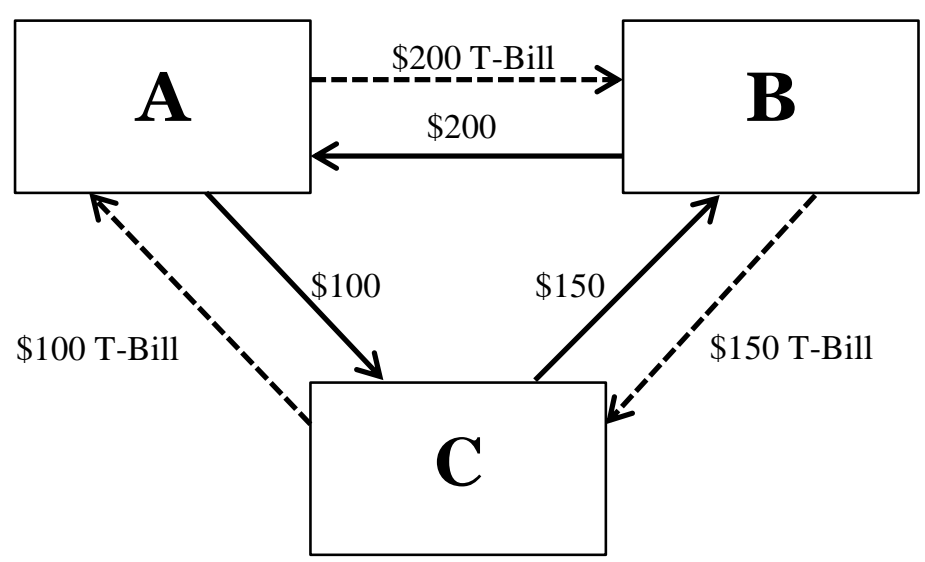

In this market scenario, the total value of the circulating cash amounts to $\$ 450$ and the amount of transferred collateral totals $\$ 450$. In a bilateral market, each party bears the default risk of its counterparty.

The market structure changes completely when we introduce a CCP into the framework. A CCP intervenes once the original parties have agreed on the contractual terms of the deal and the transaction has been confirmed. Then the CCP "novates" the contracts, which means the CCP substitutes the original contract between A and B, for example, with two separate contracts that have the CCP as a counterparty respectively of A and B. In finance jargon, the CCP becomes the "buyer to every seller" and the "seller to every buyer". 188 A CCP not only novates the contracts, but also clears the transactions. More specifically, the CCP nets offsetting contractual positions, thus reducing the gross volume of the

188 Craig Pirrong, The Clearinghouse Cure, Regulation, Winter 2008-2009, at 44. 
overall transactions. For instance, looking at the example above, without a CCP, the overall value of the transactions between $\mathrm{A}, \mathrm{B}$, and $\mathrm{C}$ is $\$ 450$ and the total value of collateral transferred is also $\$ 450$. By having a CCP as the central counterparty for all of the deals, the net value of cash and collateral transfer is only $\$ 200$. As the graph below shows, for instance, $\mathrm{A}$ is obligated to make a gross payment of $\$ 100$ to $C$ and receive a $\$ 200$ payment from $B$. However, with central clearing and net settlement, $\mathrm{A}$ is entitled to a single net payment of $\$ 100$ from the CCP. The same logic and conclusions can be expanded to B and C, and apply to both cash payments and collateral transfers.

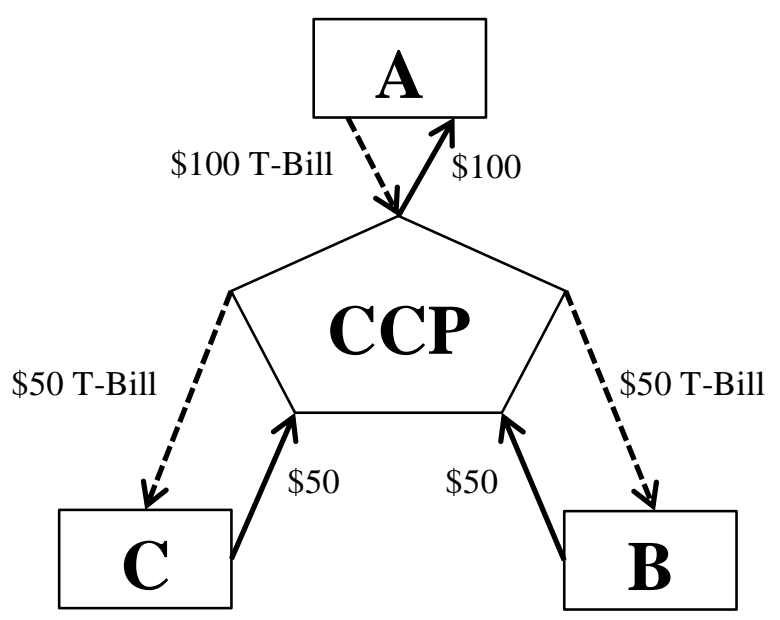

b. How do CCPs mitigate risk and increase efficiency in the repo market?

CCPs provide the repo market with certain benefits, namely stability and efficiency. The immediate consequence of having to clear a transaction is the standardization of the contractual terms. A CCP "can smoothly sort out and compress a tangle of trades" only if the repo contracts are standardized. ${ }^{189}$ Furthermore, a CCP "can make pricing public"; thus, standardization facilitates price comparison and the overall transparency of the market. ${ }^{190}$ In addition, CCPs pool, redistribute, and reduce counterparty credit risk through novation and netting of offsetting positions; reduce the overall financial risk ${ }^{191}$ in the system via multilateral netting; mitigate systemic risk by providing a loss allocation and mutualisation function; strengthen the liquidity supply for the financial market; provide more efficient use and allocation of securities as collateral (generally considered scarce resources in the financial system); prevent risk spreading; reduce the risk of run and panic in the repo market; and strengthen transparency as well as legal and operational efficiency. For these reasons, having central clearing for

\footnotetext{
189 Roe, Clearinghouse Overconfidence, supra note 185, at 1657.

$190 \mathrm{I} d$. at 1658.

191 Both risk exposure and settlement costs.
} 
repos reduces the instability in the current architecture of the bilateral and tri-party repo markets.

\section{i. CCP as counterparty credit risk assessor and mitigator}

In every repo transaction, counterparty credit risk manifests in three different forms: (1) the risk of assessing the creditworthiness of a counterparty; (2) the risk connected to the evaluation of the collateral pledged as a guarantee of the counterparty's performance; and (3) the risk that the counterparty will default and fail to meet its financial obligations under the contract. These risks are related to the fact that the contractual parties negotiate and enter into a deal in a situation of information asymmetry. A repo lender, for instance, is not in a position to gather information about the overall exposure of its borrower to short-term funding contracts. The lender finds it very expensive to monitor the creditworthiness of its counterparty; it cannot have access to data on the overall market use and distribution of specific securities pledged as collateral, and, in the event that the borrower defaults, the repo lender bears all of the losses directly.

Having a CCP at the centre of the repo market web will mitigate counterparty credit risk in four major ways. First, by novating the original repo contracts, the CCP will become the legal counterparty for all centrally cleared transactions, ensuring financial performance. Each and every repo borrower and lender would have the CCP as its lending or borrowing counterparty. By statute, CCPs cannot be involved in risky investments and their business model is based on a "matched book", which means that 'any position taken on with one counterparty is always offset by an opposite position taken on with a second counterparty."192 The peculiarity of their "matched book" activity is reflected in the maturity of the CCP's balance sheet. A CCP has "symmetrical [balance sheets] in terms of duration, [so] the clearing house accepts responsibility for its members' short-term debts only to the extent that the members can provide the clearinghouse with short-term liquid assets." 193 CCPs' business and economic function is to clear trades: they are specialized and sophisticated market utilities involved in risk management. CCPs' capital structure and internal governance are heavily regulated and subject to strict prudential oversight by public authorities, making them more reliable than other market participants.

Second, as the numerical example shows, CCPs manage multilateral transactions in a more effective way than the bilateral settlement of trades. CCPs net, or in jargon "clear", offsetting transactions on a multilateral basis. 194 "This means that a delivery of a security due to the CCP from parties A and B can be netted off against deliveries of the same security due on the same day from the CCP to parties C and D. The same applies to cash payments. This produces much

\footnotetext{
192 Rehelon, supra note 171.

${ }^{193}$ Richard Squire, supra note 185, at 859 . CCPs' activities do not involve maturity transformation.

194 See Roe, Clearinghouse Overconfidence, supra note 185, at 1660-1662; Squire, supra note 185, at 863- 869, 886-887, 899-902, Squire argues that 'multiparty netting redistributes insolvency risk but not illiquidity risk; rather, it creates value by preserving liquidity that otherwise would be lost through bankruptcy.'
} 
smaller net exposures than bilateral netting, in which each party can only net transactions with the same counterparty." 195

Third, CCPs have access to better information, both on the overall exposure of one counterparty in the repo market and on the distribution and use of collateral in the system. In fact, by collecting and managing collateral for all cleared transactions, CCPs can assess how specific securities are distributed in the system, how much exposure to specific pledged securities exists, etc. This last point is closely connected to fire sale risk, which occurs when there is a sudden need to liquidate specific securities pledged as collateral. As the Crisis revealed, when many repo lenders tried to recoup their defaulted loans by liquidating massive amounts of asset-backed securities pledged as collateral in repo deals, ABSs dropped in value and repo lenders had to apply huge discounts to liquidate their positions. ${ }^{196}$

Fourth, CCPs have in place more effective mechanisms to respond to the default of a clearing counterparty. ${ }^{197}$ While in a bilateral repo, the non-defaulted party must directly absorb the losses caused by the default of its counterparty, in a centrally cleared transaction, the CCP can manage the default of one of its counterparties in a more orderly and less costly way, redistributing the losses among all clearing members. A CCP can utilize diverse mechanisms to cover potential losses. First, it can try to auction the defaulted counterparty's position. If unsuccessful, it can try to sell the pledged securities on the markets. If the proceeds of the sale are still not enough to cover the exposure left by the defaulted counterparty, the CCP can - as a last resort - draw resources from what is known as the "default waterfall" fund, which includes different forms of funding that derive not only from the defaulted counterparty, but also from the other clearing members of the CCPs. The purpose of this mechanism is to mutualize and absorb the losses from the member's default among all the other clearing members and the CCP itself, before the losses and the risk spread across the market and reach systemic proportions. The next section will address in more detail how a CCP can act as a systemic risk mitigator in the repo market.

\section{ii. CCP as systemic risk mitigator and stabilizer of the risk of run}

The events that occurred in the repo market during the Crisis revealed how the interconnectedness of repo market participants systemically propagated panic,

\footnotetext{
195 See ICMA, supra note 30, at 24.

196 See Section II.B. for a more detailed analyses.

197 See Squire, supra note 185, at 863-872. Squire identifies two main forms of "loss distribution" performed by CCPs: loss externalization and loss mutualisation. 'Loss externalization refers to how the clearing house shifts losses from clearing house members to the insolvent member's outside (nonmember) creditors. Loss mutualisation refers to how the clearinghouse spreads by remaining, nonexternalized losses among the surviving members.' Loss externalization is mainly achieved by multiparty netting - the compensation of offsetting positions - and margin collection. When multiparty netting and the posted collateral proves insufficient to cover the losses of the failed member to the CCP, the CCP resorts to loss mutualisation mechanisms - the so-called "default waterfall", which distributes the losses equally among all of the non-defaulted clearing members and the CCP itself.
} 
ultimately leading to a freeze in the market. The first signs of scepticism about the soundness of the repo market started to circulate when Countrywide Securities revealed its liquidity shortage, then became more acute when Bear Stearns merged with JP Morgan Chase. When the bilateral and tri-party repo markets faced a run, as repo lenders withdrew from the market and tried to fire-sale the pledge collateral assets in an attempt to recover their exposure, repo borrowers were unable to finance their market activities because of the general loss of confidence in the securities commonly pledged as collateral in repo transactions. Would the situation have been different had CCPs been operating in the repo market? Yes: there is evidence that the "run on repo" was more acute in the bilateral repo market. ${ }^{198}$ This paper does not argue that CCPs would have prevented the Crisis, but the presence of FMI and CCPs in the repo market would certainly have contained the use of taxpayers' money from the get-go. It would also have mitigated the systemic losses related to the market freeze and stabilized the spread of panic among market participants. ${ }^{199}$

A CCP is a peculiar entity because it is a financial market participant that operates under a unique regime. CCPs are subject to stricter risk management practices than other market participants; their core business is the clearing, multilateral netting, and settlement of risk exposures of offsetting positions. As such, CCPs' capital structure includes specific capital buffers that are set up to absorb and eventually mutualize losses in case one or more clearing members default on their obligations. The nature of the "default waterfall" - the term used to identify all lines of defence that a CCP has in place to respond to the default of one of its members - is the mutualisation of potential losses in order to specifically avoid the risk that the default of one counterparty might spread throughout the financial system. ${ }^{200}$ Being the prime counterparty for all trades does not simply imply that the CСP concentrates the risk in a single place; rather, it refers to the CCP's ability to act as a stability buffer in the event of a run on the system. ${ }^{201}$

\footnotetext{
198 See Gordon \& Metrick, supra note 10, at 279.

${ }^{199}$ Scholars like Mark Roe and Craig Pirrong, focusing on the post-Crisis mandate of the central clearing of OTC derivatives, raise critiques of the ability of CCPs to reduce systemic risk, arguing conversely that mandatory clearing may increase systemic risk. See Craig Pirrong, supra note 182 at 54 ('[T] here are many channels by which formation of a [clearinghouse] affects systemic risk, and some of these tend to increase systemic risk;'); Mark Roe, Systemic Costs of Derivatives' Priorities, 63 STAN L. Rev. 539,586-87 (2011); Mark Roe, Clearinghouse Overconfidence, supra note 185 at 1663-1691(describing how a clearinghouse may increase systemic risk).

200 See Adam Levitin, Response: The Tenuous Case for Derivatives Clearinghouses, 101 GeO. L.J. 445, 462 (arguing that a sound and well-designed guarantee fund makes a CCP a "fortress of capital").

201 See Gary Gorton, Clearinghouses and the Origin of Central Banking in the United States, 45(2) J. ECON. HIST. 277 (1985) (discussing the role of clearinghouses in bank panics in the pre-Fed scenario). Gorton analyses the double role performed by clearinghouses in the banking system. Clearinghouses were introduced as organized markets to "clear" checks and broadly demand deposit contracts. Yet, in times of panic, '[c]learinghouses were institutional responses to both the possibility and the actuality of $[\ldots]$ information externalities' connected to the inability of depositors to 'identify bank-specific risks[,] so all banks were vulnerable to runs,' $i d$. at 279-280. 'When a panic occurred, the structure of the banking industry was radically altered by the metamorphosis of the clearinghouse into a single, firm-like organization $[\ldots][\mathrm{T}] \mathrm{he}$ first act of the clearing house facing a panic [...] was the suspen[sion] of the publication of individual
} 


\section{iii. CCP as liquidity valve}

While this paper has thus far examined CCPs in terms of how they intervene to mitigate systemic risk, reduce panic risk, etc., it is now time to acknowledge another important function performed by CCPs: their "liquidity partitioning" function. This term defined by Richard Squire, ${ }^{202}$ refers to what CCPs do in the event that a member defaults, i.e., 'faster cash payouts when a trading firm fails' an important and as yet unexplored benefit of central clearing. ${ }^{203}$ Multiparty netting is the key mechanism that makes CCPs a source of liquidity and certainty in the financial market, and which makes faster payout possible.204 'The clearinghouse accelerates cash payout by engaging in liquidity partitioning: it cordons off a portion of a bankrupt firm's cash assets and short-term liabilities, and it applies the first towards immediate repayment of the second. ${ }^{205}$ In addition, 'the more netting the clearinghouse permits, the greater [is] its capacity to reduce illiquidity and uncertainty in a crisis...'206 By doing so, the CCP diverts 'cash that otherwise would enter the bankruptcy estate (where demand for liquidity is low)...to financial-sector creditors (whose demand for liquidity is high). Like a bailout, the clearinghouse improves the financial sector's cash ratio,' but without the injection of public money. ${ }^{207}$

\section{iv. From tri-party clearing banks to standalone specialized CCPs}

As addressed in Section I.A., parallel to the OTC bilateral repo market, the US repo market has a considerable volume of trades concluded and processed in the tri-party repo system. ${ }^{208}$ The US financial system relies heavily on two tri-party clearing banks as sources of liquidity for the financial system; if these banks were to fail, there would be no more liquidity in that system. In the tri-party repo market, there are only two clearing agent banks - Bank of New York Mellon and JP Morgan Chase - that facilitate the settlement of repo transactions. They are not clearing counterparties, but clearing agents for cash and collateral flow. More precisely, clearing banks maintain cash and securities accounts for dealers and cash investors, and they settle repo transactions on their own balance sheets. A clearing bank clears the transaction by transferring, at the deal date, securities from the

\footnotetext{
bank balance sheet information [and the] publi[cation] [...][of] the aggregate of all members. This was generally accompanied by a joint suspension of convertibility of deposit into currency.' Id. at 280. Through such action, the clearinghouse transformed "bank-specific information" into aggregated information, thus eliminating the risk of spotting the weak link in the chain, which could have triggered the run. In addition, in order to keep the banking system running, the clearinghouse issues "loan certificates", jointly guaranteed by all clearing members, which could be used in the clearing process: '[T] he existence of clearinghouses suggests that private agents can creatively respond to market failure.' 202 See Squire, supra note 185, at 858; 891-906.

203 Id. at 891.

204 Id.

205 Id.

206 Id. at $905-906$.

207 Id. at 921

208 See Section II.A.1.
} 
dealer's securities account to the cash investor's securities account, and by transferring cash from the investor's cash account to the securities dealer's cash account. Then, at the maturity and closing date, the clearing bank settles the repo by performing the same transfers in the opposite direction. In addition to the settlement and custody of the cash and securities transfers, the clearing bank also performs collateral management functions, and, as critically shown by the financial crisis, their business model keeps them from extending credit lines to the repo parties. This business model presents serious concerns to market efficiency and market stability - concerns that would be more effectively addressed by moving repo clearing to standalone clearing utilities.

Both Bank of New York Mellon and JP Morgan Chase are actively involved in competitive financial markets. ${ }^{209}$ This results in a triple order of problems. First, the repo clearing market is not competitive, and the two clearing banks act in a dominant oligopolistic position. Second, being active market participants themselves, the two clearing banks are potentially heavily exposed to moral hazard. The fact that the tri-party clearing organization sits within these large, complex financial institutions might trigger their excessive risk-taking in other areas precisely because, due to their significant utility function, they expect to be backed up by the government in a situation of financial distress. Third, Bank of New York Mellon and JP Morgan Chase exist in a perpetual conflict of interest. Although these two clearing banks compete with one another and with other market participants as they strive to increase their market shares, they each provide their competitor with an essential utility function: they clear repo transactions in order to fund their investments. In this situation, the clearing banks, aware of the heavy reliance of their market competitors on tri-party repo funding and exploiting their renting position, might charge higher prices for their clearing activities, reducing the competitiveness of the other market participants.

For these three reasons, moving repo clearing into standalone specialized entities would increase the competiveness in the repo market, eradicate the potential conflict of interest and moral hazard that lies in the current business structure of the repo clearing banks, and simplify the supervision of clearing activities. ${ }^{210}$ Although moving repo clearing to CCPs might impose additional operating costs onto market participants, it would enable the investment in more robust clearing technologies and lead to a more resilient wholesale funding market for broker banks. ${ }^{211}$

\footnotetext{
${ }^{209}$ Both BNYM and JPMC are registered with the Fed as "bank holding companies" and "financial holding company" under the Bank Holding, 12 U.S.C. \1841(1) et seq.; 12 U.S.C. \1841(3)(I)(1). 210 See Darrell Duffie, How to Fix the Tri-Party Repo System, YouTuBE.Com https://www.youtube.com/watch?v=lvheZyA_90 (last visited August 10, 2015); Darrell Duffie, Fixing the Biggest Pipes in the Plumbing of Our Financial System, YouTuBE.COM https://www.youtube.com/watch?v=KOYaP41qaqI (last visited August 10, 2015); Duffie, Replumbing Our Financial System, supra note 10 at 259-266.

211 See Duffie, Replumbing Our Financial System, supra note 10 at 266.
} 


\section{CONCLUSION}

The repo market is an essential part of the plumbing of the financial system. Financial institutions and the market heavily rely on it as a crucial source of financing and liquidity. The Crisis, however, unveiled serious structural flaws in the repo market structure - weaknesses that call for us to reassess whether the repo market needs to be reformed. Repos perform economic functions equivalent to bank deposits and secured loans, and share with them the very same vulnerabilities. Furthermore, the repo market has evolved as an OTC market without falling under any regulatory framework.

The Crisis exposed the failures that are inherent in the repo system. The repo market is highly opaque, dominated by a few market participants in dominant and rent-seeking positions, intrinsically unstable and prone to run due to the maturity and liquidity mismatch of repo transactions, and vulnerable to panics due to the absence of any public or private stability buffers or mechanisms. Finally, the core role that the repo market plays in the liquidity supply makes any crisis within it a systemic one.

Despite all of these failures and the responsibility of the repo market for propagating the Crisis throughout the financial system, regulators decided not to intervene and kept the repo market out of the post-Crisis reform agenda. This paper challenges the positions of those regulators and policymakers and offers a regulatory blueprint on how to build a more sound and efficient repo market.

Building on the post-Crisis reforms of OTC derivatives, this paper suggests that the use of standalone CCPs in the repo market would foster transparency, mitigate systemic risk, and strengthen the liquidity supply in the financial market. Furthermore, the ancillary evolution of trading venues and trade repositories in the repo market would support overall market efficiency by providing market participants with more information for risk assessment, and would sustain market stability by offering comprehensive information on the market. 